IZA DP No. 9215

Trade, FDI, Migration, and the Place Premium: Mexico and the United States

Davide Gandolfi

Timothy Halliday

Raymond Robertson

July 2015 


\title{
Trade, FDI, Migration, and the Place Premium: Mexico and the United States
}

\author{
Davide Gandolfi \\ Macalester College \\ Timothy Halliday \\ University of Hawaii at Manoa, \\ UHERO and IZA
Raymond Robertson
Macalester College and IZA
Discussion Paper No. 9215
July 2015

IZA

P.O. Box 7240
53072 Bonn
Germany

Phone: +49-228-3894-0

Fax: +49-228-3894-180

E-mail: iza@iza.org

\begin{abstract}
Any opinions expressed here are those of the author(s) and not those of IZA. Research published in this series may include views on policy, but the institute itself takes no institutional policy positions. The IZA research network is committed to the IZA Guiding Principles of Research Integrity.

The Institute for the Study of Labor (IZA) in Bonn is a local and virtual international research center and a place of communication between science, politics and business. IZA is an independent nonprofit organization supported by Deutsche Post Foundation. The center is associated with the University of Bonn and offers a stimulating research environment through its international network, workshops and conferences, data service, project support, research visits and doctoral program. IZA engages in (i) original and internationally competitive research in all fields of labor economics, (ii) development of policy concepts, and (iii) dissemination of research results and concepts to the interested public.
\end{abstract}

IZA Discussion Papers often represent preliminary work and are circulated to encourage discussion. Citation of such a paper should account for its provisional character. A revised version may be available directly from the author. 


\title{
ABSTRACT \\ Trade, FDI, Migration, and the Place Premium: Mexico and the United States*
}

\begin{abstract}
Large wage differences between countries ("place premiums") are well documented. Theory suggests that factor price convergence should follow increased migration, capital flows, and commercial integration. All three have increased between the United States and Mexico over the last 25 years. This paper evaluates the degree of wage convergence between these countries during the period 1988 and 2011. We match survey and census data from Mexico and the United States to estimate the change in wage differentials for observationally identical workers over time. We find very little evidence of convergence. What evidence we do find is most likely due to factors unrelated to US-Mexico integration. While migration, trade, and FDI may reduce the US-Mexico wage differential, these effects are small when compared to the overall wage gap.
\end{abstract}

JEL Classification: F15, F16, J31, F22

Keywords: migration, labor-market integration, factor price equalization

Corresponding author:

Raymond Robertson

Macalester College

1600 Grand Ave.

St. Paul, MN 55105

USA

E-mail: Robertson@macalester.edu

\footnotetext{
* We thank participants at the University of Hawaii Applied Micro Workshop, the Pacific Conference for Development Economics at UCLA, The LBJ School at the University of Texas at Austin, Tulane University, the Bush School at Texas A\&M, the Chicago Fed and the Western Economic Association 2015 meetings in Honolulu for useful feedback. Finally, we would like to thank Kristin Butcher, John Kennan and David McKenzie for useful discussions. This paper we previously circulated under the title "Globalization and Wage Convergence: Mexico and the United States".
} 
Recent papers have renewed interest in understanding equilibrium differences in earnings levels across countries. Clemens et al. (2008) use individual-level data from 43 countries to estimate the "place premium" for observationally identical workers. Kennan (2013) argues that if these differences are due to productivity then the welfare losses from migration restrictions are very large. On the other hand, neoclassical theory suggests that restrictions on trade (and possibly investment) might also contribute to the place premium. Indeed, part of the motivation developing countries have in pursuing trade agreements is the promise that increased trade will help close the wage gap between developing and developed countries (factor price equalization).

The goal of this paper is to evaluate the stability of the place premium over time in an environment of reduced trade restrictions, increased trade, rising foreign investment, and significant migration. Over the last two decades, commercial integration between the United States and Mexico significantly increased. Between 1994 and 2011, trade in goods between the two countries quadrupled in value, increasing from $\$ 108.39$ billion to $\$ 461.24$ billion (U.S. Census Bureau). The value of U.S. goods exported to Mexico increased from \$50.84 to \$198.39 billion, while the value of Mexican goods exported to the United States increased from $\$ 49.49$ billion to $\$ 262.86$ billion. In 2011, total exports to Mexico accounted for 13.4 percent of overall U.S. exports and total imports from Mexico accounted for 11.9 percent of overall U.S. imports (Office of the United States Trade Representative). By 2012, the total value of trade between Mexico and the U.S. closely approached half a trillion dollars.

GDP per capita has also increased in both countries. In constant 2005 U.S. dollars, U.S. GDP per capita increased from \$32,015 to \$43,063 between 1992 and 2012. While Mexico has had some macroeconomic setbacks, such as the December 1994 peso crisis, recovery has generally been rapid. In constant 2005 U.S. dollars, Mexican GDP per capita increased from $\$ 6,628$ to $\$ 8,215$ over the same time period. ${ }^{1}$ Rather than converge, however, Mexican GDP per capita and U.S. GDP per capita grew apart. The ratio of Mexican to U.S. GDP per capita fell from 20.7\% of U.S. GDP per capita in 1992 to 19.2\% in 2011.

The persistent and seemingly growing GDP per capita gap has been noted in the literature as an important research question (Hanson 2010), partially because it is at odds with neoclassical trade theory, migration theory, and early applied general equilibrium predictions of the effects of

\footnotetext{
${ }^{1}$ World Bank Development Indicators. See http://data.worldbank.org/data-catalog/world-development-indicators.
} 
NAFTA. ${ }^{2}$ The neoclassical Heckscher-Ohlin-Samuelson (HOS) framework, one of the canonical trade models, predicts that trade liberalization would lead to convergence in the prices of traded goods, which in turn would induce factor price convergence. In addition to the significant increase in trade noted above, Robertson, Kumar, and Dutkowsky (2009) find strong support for convergence in goods-level prices between Mexico and the United States, making the lack of convergence in income inconsistent with the prediction of trade models. ${ }^{3}$

The lack of convergence in GDP per capita is also at odds with some labor-based migration models. ${ }^{4}$ At the most basic level, an increase in labor supply from migration should reduce wages if the aggregate labor demand curve is downward sloping. Although debated, Borjas (2003) provides empirical evidence for the downward-sloping labor demand curve. ${ }^{5}$ Emerging evidence also suggests that emigration increases wages of workers who stay behind. Mishra (2007) provides evidence that Mexican emigration bids up Mexican wages, and Elsner (2013a) finds similar results for Lithuania. Elsner (2013b) finds that emigration's effects are not uniform throughout the wage distribution. Convergence should be the most prominent for demographic groups with the highest propensity to migrate. Such movements would tend to raise Mexican wages and depress U.S. wages, thereby reinforcing the effects of free trade on wage convergence. Alternatively, migration could increase the differential in the presence of agglomeration effects (Brezis and Krugman 1996, Giovanni et al. 2015), making our application relevant for the debate on migration's effect on wages as well.

Despite the lack of convergence in the per capita GDPs of Mexico and the United States over the past 25 years, there are ample reasons that would point towards increased wage

\footnotetext{
${ }^{2}$ See Brown (1992) for a survey of early general equilibrium models of NAFTA.

${ }^{3}$ The lack of evidence of factor price equalization generally has prompted many to question the validity of neoclassical HOS-type models. Schott (2003) finds that we live in a "multi-cone" world that precludes factor price equalization. Davis and Mishra (2007) suggest that ignoring important variation between the mix of factors employed in the production of domestic and imported goods obfuscates the possible effect that free trade may depress the wages of workers in relatively labor-intensive domestic industries. Goldberg and Pavcnik (2007) discuss evidence of rising inequality in poorer countries in the wake of many trade liberalizations in the eighties and nineties, which is very much at odds with a standard HOS story of how globalization should unfold. The authors provide numerous reasons why the predictions of the standard HOS theory may not hold in the data such as technology, the pattern of tariff reductions, and within-industry shifts.

${ }^{4}$ It is possible to analyze migration using general-equilibrium trade models. In the HOS framework, immigration is generally analyzed through the Rybczynski and Factor Price Insensitivity theorems. Under the assumptions that the two countries are in the same diversification cone and are small enough for immigration to have no effect on output prices, these theorems predict that immigration has no effect on wages because immigrants are absorbed through changes in the production mix.

${ }^{5}$ For example, Card $(1990,2001)$ argues that the evidence for migration's effect on wages is weak.
} 
convergence over this period, particularly for demographic groups that are most affected by trade, foreign direct investment (FDI), and migration. In this paper, we carefully measure Mexico-U.S. wage differentials (the place premium) for specific demographic groups and track these over time. We then quantify the extents to which trade, FDI, and migration may have helped to narrow these differentials.

While no specific papers have attempted to answer these questions, several related papers focus on within-country convergence or short-run convergence. Some studies have investigated wage convergence within countries and early studies of the Mexican labor market did indeed detect evidence of it (Hanson 1996, 1997, and Chiquiar 2001). Another study by Robertson (2000) finds a strong, positive correlation between short-run wage growth in the United States and short-run wage growth for Mexican workers who reside on the border with the United States. Hanson (2003) also finds a similar result. Robertson (2005), however, finds no evidence that NAFTA increased the estimated degree of labor market integration between the United States and Mexico as measured by the transmission of short-run shocks.

Our paper differs from these others along a number of dimensions. First, unlike Robertson (2000), we are not concerned with the short-term transmission of wage shocks across national boundaries. Second, we are not concerned with regional convergence within Mexico. Rather, we carefully document the evolution of Mexico-U.S. wage differentials over a long horizon and try and understand the mechanisms behind these movements. So, we provide a more descriptive "bird's eye" view of the data that is then interpreted through the lens of some workhorse theories (e.g. HOS). We believe this to be an important omission from the literature.

We do this by using two complementary methodologies and four data sources. The first approach matches quarterly survey data from the Current Population Survey (CPS) in the United States and the Encuesta Nacional de Ocupacion y Empleo (ENOE) in Mexico. ${ }^{6}$ The second approach employs census data from Mexico and the United States for three different time periods. Clemens et al. (2008) use very similar data and a similar approach. The main difference is that they compare a single cross section for multiple countries; we compare a single country pair and multiple time periods.

\footnotetext{
${ }^{6}$ In addition to the ENOE, we use its predecessors, the Encuesta Nacional de Empleo (ENE) and the Encuesta Nacional de Empleo Urbano (ENEU).
} 
When using the survey data, we first divide Mexican and U.S. working-age people into 45 age-education cells. Comparing exclusively Mexican and U.S. workers in the same educationage cell effectively controls for variation in returns to skill and allows us to use quarterly data to identify time-series patterns. The disadvantage is that it focuses only on workers residing in urban areas in Mexico.

The second approach overcomes this disadvantage by using census data that include rural workers. These data have the added advantages that the sample sizes are larger, they have more complete information about hours worked, and they capture long-run differences. The disadvantage of census data is that the data are observed only once every ten years. With these data, we first compare mean wage differentials by education and age cell and look at how these have evolved over time. Next, we look deeper into the data and investigate how the relative wage distributions have evolved over time by comparing changes in a given percentile for a given age and education level.

On the whole, the results demonstrate that there has been very little, if any, wage convergence between the U.S. and Mexico over time. While the 1994 peso crisis obviously contributed to the lack of convergence, we find some evidence for divergence even beyond the effects of the peso crisis. Although there is evidence of some convergence in the high-migration groups, this seems to be primarily due to falling U.S. wages at the bottom of the U.S. income distribution, as opposed to rising Mexican wages.

While this "bird's eye” look at the data does not appear to indicate much wage convergence despite large increases in economic integration, a more detailed look at the data does suggest that investment in Mexico and migration may have narrowed the US-Mexico wage gap, but only to a small degree. Indeed, the census data reveal that there was convergence in the border region of Mexico relative to the interior in the 1990s, but divergence in the 2000s. Since FDI in Mexico is mainly concentrated in the border, FDI may indeed have led to some initial wage convergence. We also estimate some common specifications from the literature on migration and wages and find that there is some evidence that increased migration can narrow the place premium.

Despite this suggestive evidence that migration, FDI, and trade may arbitrage the USMexico wage differential, their effects are very modest when compared to the overall difference. Particularly, even if we adopt methods from the literature that are the most likely to deliver the 
largest effects of migration on wages, an impossibly high level of migration would be needed to achieve wage equalization. In addition, when we compare the evolution of Mexican wages in its border and its interior, the wage gains in the border during the 1990s are relatively modest when compared to the overall differential. We conclude that the place premium is largely stable, even following large reductions to trade and investment barriers and high migration. This may indicate that the US-Mexico place premium has more to do with productivity differentials than it has to do with trade, FDI, and migration barriers.

We begin by discussing the four data sources that we use in Section I. We then present some descriptive empirical results in Section II and III in which we elucidate some of the patterns in the evolution of Mexico-U.S. wage differentials over the past 25 years. We then investigate some of the mechanisms that may be behind what convergence we do see in the previous sections in Section IV. Finally, we conclude in Section V.

\section{Data}

We use four datasets that represent two separate types of data. Both datasets are broadbased in the sense that they cover both formal and informal-sector workers. The first type is quarterly urban household survey data that cover the 1988-2011 period. U.S. household survey data cover both urban and rural U.S. households, but the rural population is relatively small. Second, we use census data that have two advantages over the survey data. The first is that the Mexican census data contain much more accurate information about rural households. The second is that the sample sizes are much larger so we can obtain a more detailed understanding of what is happening to the relative wage distributions. That said, they have the disadvantage of only being available in ten-year intervals.

\section{Household Survey Data}

We extract all data on Mexican households from the Encuesta Nacional de Empleo Urbano (ENEU) and the Encuesta Nacional de Empleo (ENE) over the period 1988-2004 and from the Encuesta Nacional de Ocupacion y Empleo (ENOE) over the period 2005-2011. U.S. household data are from the Merged Outgoing Rotation Groups (MORG) data of the Current Population Surveys (CPS) over the entire 1988-2011 period. We exclude working-age adults who have zero or unreported earnings. The sample is further restricted to adult males between 19 
and 63 years of age. Focusing on male workers allows us to ignore the issue of self-selection on the participation of women in the labor force, as well as the effect of changes to self-selection patterns over time and between the United States and Mexico. The Mexican data are reported as monthly earnings. The U.S. data report weekly earnings. We multiplied reported U.S. weekly wages by 4.33 to transform them into monthly wages.

Following Chiquiar and Hanson (2005), all earnings measures are converted into 1990 U.S. dollar units. Mexican earnings are converted into dollars by using simple quarterly averages of the daily official exchange rates published by the Mexican Central Bank (Banco de Mexico 2013). We then deflated the wages to 1990 dollars using the quarterly average of the U.S. Consumer Price Index (CPI) (Bureau of Labor Statistics). ${ }^{7}$ Also as in Chiquiar and Hanson (2005), we only use Mexican wages that are between \$0.05 and \$20.00 and U.S. wages that are between $\$ 1.00$ and $\$ 100.00$.

ENEU/ENE/ENOE surveys have been extended to significantly more rural areas over the last two decades. In order to reduce the bias generated by greater participation of the rural Mexican population, we restrict the sample to workers from major metropolitan areas that have consistently been included: Mexico City, the State of Mexico, San Luis Potosí, Leon, Guadalajara, Chihuahua, Monterrey, Tampico, Torreon, Durango, Puebla, Tlaxcala, Veracruz, Merida, Orizaba, Guanajuato, Tijuana, Ciudad Juarez, Matamoros, and Nuevo Laredo. No geographical restrictions have been imposed on MORG data.

Descriptive statistics for the raw survey data are displayed in Table 1. Each column gives an average of quarterly observations collected over a four- or five-year period. The average U.S. monthly wage ranges from $\$ 2,333$ to $\$ 2,502$, and it has remained roughly constant from 1988 to 2011. The average constant-dollar value of the Mexican monthly wage ranges from \$276 to \$345 with marked declines following the peso crisis and the global financial crisis. The average age of the U.S. workforce has increased steadily between 1988 and 2011, from 37 to 40 years. The average age of the Mexican workforce has also risen steadily, from 35 years in 1988-1994 to 37 in 2008-2011.

\footnotetext{
${ }^{7}$ We also converted Mexican wages to 1990 U.S. dollars by first deflating the wages to 1990 pesos using the Mexican CPI and then converting them to U.S. dollars using the 1990 exchange rate. Overall, this alternative method did not make too much of a difference. We conduct a comparison of these two deflation methods in the appendix.
} 
The U.S. workforce is significantly more educated than the Mexican workforce, with about $90 \%$ of all workers in each time period having at least completed high school education. By contrast, the number of Mexican workers with more than a high school education ranges from $16 \%$ in 1988-1994 to 21\% in 2008-2011. The average education of the Mexican workforce has increased significantly. ${ }^{8}$ The steady rise in the number of high school graduates and college attendees has been accompanied by a steady decline in the number of workers with 0-4 years of education, which dropped from 20\% in 1988-1994 to 11\% in 2008-2011. The largest gains emerge in the 9-12 category because Mexico raised the compulsory education requirement from 6 to 9 years in $1992 .^{9}$

Ideally, survey data would collect information from surveyed individuals at regular intervals, and neatly organize it as panel data. In the absence of such data, it is possible to use a time series of cross-sectional surveys (Deaton, 1985). We create 45 age-education cells when using the survey data. In the absence of significant changes to the composition of the cells, the average behavior of each cell over time should approximate the estimates obtained from genuine panel data (Deaton, 1997). Since our focus is not on wage growth of individuals over time, we do not "age" the cells.

Working-age adults in each sample are subdivided into five education categories and nine age categories. The first age group includes workers aged 19-23 years old; the second includes workers aged 24-28, the third those aged 29-33, and so forth. The first education group includes adults with 0-4 years of education; the second includes adults with 5-8 years of education; the next comprise those with 9-12, 13-16 and finally more than 16 years of education. These categories are chosen to match the classification used in the census data (described below) and are roughly comparable to those employed by Robertson (2000), Borjas (2003), and Mishra (2007). ${ }^{10}$ Unlike Borjas (2003), we are able to identify greater variation in the group of working adults who have not completed high school. We exclude workers with zero or unreported amounts of education. Once workers are assigned to the 45 categories, we take the average wage

\footnotetext{
${ }^{8}$ Lustig et al. (2012) argue that the increase in the supply of education in Mexico played a significant role in reducing income inequality in Mexico.

${ }^{9}$ See http://wenr.wes.org/2013/05/wenr-may-2013-an-overview-of-education-in-mexico.

${ }^{10}$ One might be reasonably concerned that workers in the same cells are not comparable across countries. In fact, cell comparability has been contentious in the literature. Alternative matches, such as Mexican workers with 9-11 years of schooling being matched with U.S. workers with 6-8 years of schooling, might be justified using occupation data. Since a thorough analysis of such matches might be worthy of its own study, we consider alternative matches to be beyond the scope of the current paper and instead follow the convention established in these papers.
} 
of each cell with the sample weights. We then calculate the wage differential by subtracting the log of the mean wage of each Mexican cell from the matched log of the mean wage of each U.S. cell. ${ }^{11}$

Rather than graph the individual wage differences for all 45 cells, Figure 1 presents the median, minimum, and maximum differential for each time period. Several significant macroeconomic events are immediately apparent. The December 1994 peso crisis led to the rapid devaluation of the peso against the U.S. dollar, as nominal exchange rates doubled from 4 pesos/U.S. dollar to 8 pesos/U.S. dollar in a few months. The drastic change in exchange rates and the subsequent erosion of purchasing power represented a significant shock to Mexican wages. The peso/U.S. dollar exchange rate has been floating ever since. At least some of the increase in Mexican real wages between 1994 and 2001 may be attributed to a rebound in purchasing power experienced by Mexican workers as the effects of the crisis waned over time. The increase in wages reverses around 2001, which coincides with both the U.S. recession (March 2001) and China entering the WTO (December 11, 2001). ${ }^{12}$ Recovery resumes around 2005 and differentials fall until the Financial Crisis and Great Trade Collapse in October 2008. Compared to Mexican wages, U.S. wages are relatively stable. Real wages have experienced no significant expansion or contraction over the sample period, but may appear to decline slightly after 2001.

To formally identify structural breaks in the average differential, we apply tests for unknown breaks described by Vogelsang and Perron (1998). Figure 2 plots the relevant additive outlier test statistic. The local extremes of the test statistic indicate a trend break. The peso crisis is the most significant break, but a smaller local maximum appears around 2000. The 2000 break roughly corresponds to the 2001 U.S. recession and China's entrance into the World Trade Organization. Therefore, in the empirical work that follows, we include structural breaks in both 1994 and 2001. ${ }^{13}$

\footnotetext{
${ }^{11}$ We also generate the same results using the mean of the person-level log monthly earnings and get basically identical results.

12 Dussel, Peters, and Gallagher (2013) argue that China had a significantly negative influence on NAFTA trade.

${ }^{13}$ In unreported results, we also analyze the standard deviation of the earnings differentials across cells. The standard deviation of wage differentials across cells exhibit breaks at the times indicated by the Vogelsang and Perron test statistic. The standard deviation rises steadily until the end of the sample, again supporting the use of multiple structural breaks.
} 
While the differentials of individual cells generally move together, there are some differences across cells. The differential for workers with 0-6 years of education and 34-38 years old exhibits significant peso crisis effects. Around 2001, however, the recovery seems to stop and the differential grows through the 2000s. The pattern for workers with 12-16 years of education and 54-58 years old reveals a smaller peso crisis effect, but a rising wage gap during the 2000s. The wage gap for a "high migration" cell (19 to 23 year-old workers with 6-9 years of education) either remains flat or falls slightly throughout the 2000s. These differences across cells are consistent with the idea that migration helps to integrate markets by closing the wage differential across countries because migration propensities across these groups are different.

Figure 3 shows the percentage of Mexican-born workers in the U.S. by age and education for each of the 45 cells. Most Mexican-born workers in the U.S. are younger. In addition, Mexican-born workers in the United States comprise a progressively declining share of the workforce among older groups. We also see that the bulk of Mexicans residing in the United States tend to be less educated.

\section{Census Data}

We employ three years of census data from Mexico and the US: 1990, 2000 and 2010 (Minnesota Population Center 2014 and Ruggles, et al. 2010). We use a 10 percent sample from the Mexican census. For the years 1990 and 2000, we use a 5 percent sample from the U.S. census. For 2010, we employ the American Community Survey, which is a 1 percent sample of the population.

The sample selection criteria that we use for the census data mimic that of the survey data. Specifically, we include men between ages 19 and 63 who report positive income in the previous year. In Mexico, hourly wages are constructed by taking monthly earnings and then dividing by reported hours worked during a typical week times 4.33. In the United States, hourly wages were computed by taking reported yearly earnings and then dividing by reported usual hours worked per year. ${ }^{14}$ As with the survey data, all wages are in 1990 U.S. dollars. Mexican wages were, once again, converted to 1990 dollars by, first, converting wages in pesos to U.S. Dollars using the exchange rate for that year and then deflating the wages to 1990 dollars using

\footnotetext{
${ }^{14}$ Hours worked per year were obtained by taking usual hours worked per week times the number of weeks that the respondent reported to have worked during the year.
} 
the U.S. CPI. In the appendix, we discuss an alternative way of converting Mexican wages to 1990 dollars and we show that the difference is negligible.

We employ two samples from the Mexican census. The first is a sample of all workers meeting the criteria defined above, which we simply call the whole sample. The second is a sample of primarily urban dwellers that includes the metropolitan areas employed in the survey data. We call this the urban sample. Comparing these two is important because Mexico experienced a movement from rural to urban areas during this time period. Such a movement might affect our results if we find that urban wages are falling relative to rural wages, and such a comparison is impossible with the survey data described above.

Table 2 displays descriptive statistics from the census data. The differences between Table 1 and Table 2 are subtle and values are within the confidence intervals. We see that the average U.S. wage was between \$14.21 and \$15.07 for the three census years. In Mexico for the whole sample, average wages were between \$1.43 and \$1.59 and increased steadily over the 20 year period. The mean wages were slightly higher in the urban sample when we only employed urban dwellers. The average age in the U.S. sample ranged between 36.83 and 39.61 and increased over time. The average age in Mexico also increased over the 20 year period but ranged from 34.79 and 37.10 in the whole sample and 34.59 and 37.46 in the urban sample. Finally, as in the survey data, the statistics on years of schooling in Mexico indicate significant gains in human capital over this period. In the whole sample, the percentage of Mexicans with

0-4 years of schooling in 1990 was 29.54 percent but was only 11.99 percent in 2010. Similarly, the percentage of Mexicans with 9-12 years of schooling was 27.41 percent in 1990 but was 45.91 percent in 2010. The numbers are similar in the other sample. Figure 4 shows the percentages of Mexicans residing in the United States for 45 age and education categories. The patterns in this figure are broadly consistent with Figure 3.

\section{Descriptive Results: Household Survey Data}

Our main variable of interest is the long-run US-Mexican wage differential across ageeducation cells. The trend in the long-run differentials may be affected by exogenous shocks (e.g. trade liberalization and exchange rate shocks) and differences in migration costs and benefits across cells. To describe the changes in the long-run differential, we use a simple trend 
analysis that accounts for both the peso crisis and the 2001 trend break. Table 3 contains the results from three equations

$$
\begin{aligned}
& d \ln w_{i t}=\alpha_{i}+\delta \text { trend }_{t}+e_{i t} \\
& d \ln w_{i t}=\alpha_{i}+\delta \text { trend }_{t}+\beta \text { crisis }_{t}+\gamma \text { China }_{t}+e_{i t} \\
& d \ln w_{i t}=\alpha_{i}+\delta \text { trend }_{t}+\beta \text { crisis_trend }+\gamma \text { China_trend }_{t}+e_{i t}
\end{aligned}
$$

where the dependent variable is equal to the difference between the natural log of the U.S. monthly earnings and natural log of Mexican monthly earnings in education-age group $\mathrm{i}$ at time t. The variable trend is a time trend. In equation 2, crisis and China represent dummy variables equal to one for time periods after 1994q1 and 2001q1 (respectively). In equation 3, the crisis_trend and China_trend are equal to zero prior to their cutoff dates $\mathrm{T}$ and are equal to trend minus $\mathrm{T}$ in each subsequent period (the joint broken trend model described by Perron and Zhu 2005).

All three equations were estimated with robust standard errors clustered on cells and weighted using total cell populations (combined Mexican and U.S. cell sizes) as weights. All equations include cell fixed effects. All estimated coefficients are statistically significant at the $1 \%$ level, except the time trend in the first column. The time trend estimate in the first column is a very tightly estimated zero, which indicates no overall change in the wage differential over this period. Obviously, large macroeconomic shocks, such as the Peso Crisis, may have obscured any convergence that may have taken place. Column 2, therefore, includes controls for the post 1994 and post 2001 periods with dummy variables. The crisis effect is very large. The post 2001 period is characterized by smaller differentials, but still higher than before the peso crisis.

The joint broken trend model in column 3 shows a lack of convergence after the peso crisis and recovery period. Note that each coefficient represents the marginal trend difference in each period. The trend for each period is equal to the sum of the current period coefficient and any previous period coefficient(s). The trend (standard error) for the 2001+ period, therefore, is equal to -0.0003 (0.0008), which could be described as a precisely estimated zero value (the $95 \%$ confidence interval is -0.0019 to 0.0013 ). This period follows the recovery from the peso crisis and therefore may be a better indicator of the longer-run effects of NAFTA. This period is also 
characterized by slowing migration from Mexico into the United States. We now compare these results with those that emerge from the census data.

\section{Descriptive Results: Census Data}

We first use the census data to describe US-Mexico wage differentials by plotting the mean wage differential for education/age cells in the three census years. We plot these differentials for every age between 19 and 63 and for five educational categories using both the entire and the urban Mexican samples. The results are in Figure 5.

The figure reveals some interesting patterns. First, we see that for people with less education (i.e. 0 to 8 years of education) there was little change in the differential between 1990 and 2000 but there was a substantial decline between 2000 and 2010. This is the case in both Mexican samples. Also noteworthy is that the mean differentials are smaller when we use the urban sample; this is a consequence of urban areas being richer. Once we move on to people with slightly more years of schooling, we see a more attenuated decline between 2000 and 2010 while there still is little difference between 1990 and 2000. Finally, for the most educated cell (more than 16 years of schooling), there is little difference from 1990 to 2010. Like the survey data before, this figure shows no evidence of convergence during the 1990's, but there is some indication of a narrowing of the age gap for less educated people during the 2000's.

\section{Investigating Possible Mechanisms}

The finding of the previous section that there is very little convergence except for less educated people is interesting given that Mexico and the U.S. have become increasingly more integrated over the past 25 years. In this section, we look at the data in greater detail to try and better understand the effects of migration, trade, and FDI on the Mexico-U.S. wage differential since all three can integrate labor markets. To investigate the possibility that migration can narrow the US-Mexico wage gap, we will estimate models that are similar to those from Borjas (2003) and Mishra (2007). To investigate the potential impact of trade, we will look for evidence of Stolper-Samuelson effects by estimating the distributions of wage differentials for different educational groups. Finally, to investigate the potential impact of FDI, we will estimate border effects in Mexico since FDI is concentrated along the US-Mexico border. 


\section{Migration}

Mexican migration to the United States has inspired a large academic and public policy literature. Much of this literature focuses on understanding the demographic patterns of migration. While our data contain many demographic controls, they do not allow us to distinguish documented from undocumented migrants. Migration was rising in the 1990s when nearly 7.5 million Mexican immigrants arrived. ${ }^{15}$ The trend reversed and fell throughout the 2010s.

To investigate the impact of migration on the US-Mexico wage differential, we define three migration measures and investigate how each of these impacts the wage differential. The first (emigration) compares the total number of Mexicans residing in the United States to the population in Mexico within the same education/age cell. This produces a measure of the propensity of Mexicans to emigrate and would be appropriate when estimating the effects of emigration on Mexican wages. The second (immigration) compares the number of migrants in the United States to the population in the United States within the same education/age cell and measures immigration to the United States. This measure is appropriate when measuring the impact of Mexican immigration on U.S. wages. The third (total mobility) compares Mexican migrants to the combined Mexican and U.S. cell populations and is viewed as a measure of total mobility. This would be most appropriate when considering the effect of migration on the overall differential.

We begin by looking at the potential impact of migration on the wage differential in the survey data. To do this, we included the three measures of migration in the trend models described in Table 3. For each measure, three specifications are estimated. The first includes cell fixed effects. Cell fixed effects control for differences across cells such that the coefficient on the migrant share is identified by changes within cells. The second includes just time fixed effects. In this specification, the migration coefficient is identified by variation across cells. This specification might be best interpreted as the effect of the wage differential on migration. The third specification includes both time and cell fixed effects such that the migration coefficient is identified by changes across cells and time.

The results are reported in Table 4 and generally suggest that an increase in the migrant share, regardless of how it is measured, reduces the US-Mexico differentials (although the effect

\footnotetext{
${ }^{15}$ See Zong and Batalova (2014) for an overview of Mexican migration to the United States.
} 
is not always statistically significant). In the between-effects specifications, controlling for time such that the migration coefficient is identified across cells suggests that high-differential cells have higher migration. This is consistent with a simple migration model in which larger differentials attract more migrants. Controlling for these differences, however, shows that an increase in the number of migrants tends to drive down the differences between Mexico and the United States.

Next, we turn to the census data and estimate a somewhat standard estimation model in the migration literature (e.g. Borjas (2003) and Mishra (2007)). Specifically, we estimate

$$
w_{i t}=\beta M I G_{i t}+\alpha_{i}+\alpha_{t}+\epsilon_{i t}
$$

where $i$ is an education/age cell (as before) and $t$ is time. The variable $M I G_{i t}$ is one of the three migration measures discussed earlier for cell $i$ at time $t$ (i.e. emigration, immigration or total mobility) and the dependent variable is either Mexican wages, U.S. wages or the differential. To be consistent with Borjas (2003) and Mishra (2007), we use 45 education/age cells that were defined earlier in Figure 4. This specification identifies the impact of migration on wages by relying on variation in migration within cells. When employing Mexican wages as the dependent variable, we weight the cells by the size of the Mexican population in each cell and, similarly, when the U.S. wage is the dependent variable, we weight using the U.S. population size in that cell. As in Table 4, when using the differential as the dependent variable, we weight using the total population from the United States and Mexico in that cell.

We report the results in Table 5. The first three columns report the effects of emigration on Mexican wages. Note that while our preferred migration measure when the dependent variable is Mexican wages is the share of Mexicans residing within the U.S. as a share of Mexicans residing in Mexico in a given cell, we also employ the other two migration measures, "immigration" and "total mobility" in columns 2 and 3 for the sake of thoroughness. The next three columns (4-6) report the effects of immigration on U.S. wages and the final three columns report the effects of migration on the wage differential. The results in the top panel use the whole Mexican Sample and the results in the bottom panel only use the urban sample. 
In columns 1-3, we see do not see any evidence that emigration raises Mexican wages. In fact, the signs are reversed. This is not consistent with Mishra (2007) who finds evidence that emigration raises Mexican wages using census data. ${ }^{16}$

In columns (4)-(6), we look at the effects of immigration on U.S. wages. These estimates are all negative and most are significant. Our preferred estimate here is in column 5 where we use Mexicans as a share of the U.S. population or "immigration" as the explanatory variable. The estimate is -0.523 and indicates that a one percentage point increase in the migrant share in the United States is associated with a $0.523 \%$ decline in U.S. wages. The estimates using the measure of emigration tend to be the smallest at -0.091 in the full sample and -0.121 in the urban sample, whereas the estimates using the total migration measure tend to be the highest at -1.535 in the full sample and -0.823 in the urban sample.

Finally, in columns (7)-(9), we look at the effects of migration on the US-Mexico wage differential. Note that because the weighting schemes differed between columns 1-3, 4-6, and 79, these estimates are not simply the difference between the estimates in columns 4-6 and the corresponding estimates in columns 1-3. Because the estimates of emigration on Mexican wages have the Brazis-Krugman (1996) sign, many of the estimates of the effect of migration on the differential are positive. For example, we see this in column 7 in both panels. The only negative estimates are in Columns 8 and 9 in the bottom panel but neither of these estimates is significant. Interestingly, using what we view as the most appropriate measure of mobility in column 9, we obtain an estimate of -0.307 which is reasonably close to the corresponding estimate in column 3 of Table 4 of -0.630 .

At this point, it is important to ask, based on our estimates, how high would immigration to the United States need to be to eliminate the US-Mexico wage differential. Before we carry out this simple back-of-the-envelope calculation, however, we must reiterate that we do not find any evidence that emigration raises Mexican wages and that the negative effects on the differential are driven purely by immigration driving down U.S. wages. It is also important to

\footnotetext{
${ }^{16}$ Understanding why we do not replicate her result is beyond the scope of this paper since this is simply an auxiliary exercise intended to shed light on what might narrow the US-Mexico wage gap. Some possible reasons for the difference are that Mishra uses the 1970, 1990 and 2000 censuses and that she also uses a slightly different specification. Note that when we do use a specification that is more similar to her specification, we do get a positive sign although we think that the specification in the reported results is better since it identifies the effects of emigration completely off of variation within cells. The take-away of this is that these numbers cast doubt on the ability of migration to narrow trans-national wage gaps, in part, because some of the estimates of the effects of emigration on wages do not appear to be terribly robust.
} 
bear in mind that the methods that we used in this subsection are, indeed, controversial and much work by Card (1990 and 2001) finds smaller effects. For this exercise, this is actually not critical. One can remain agnostic about this literature but accept that using the methods of Borjas (2003) will most likely result in the largest effects of immigration wages. So, in this sense, this exercise will deliver a lower bound on the extent to which immigration will have to increase to equalize wages in Mexico and the United States.

Based on our data, within an educational group, the US-Mexico wage differential in the census is on the order of eight which translates to 2.08 log-points. ${ }^{17}$ If we use the estimate of -0.307 in column 9 in the bottom panel, we obtain that of the ratio of Mexicans in the U.S. to the total combined population of the two countries would have to be about seven to equalize wages across borders. ${ }^{18}$ Since this is impossible, this is another way of saying that these estimates do not indicate that migration can fully arbitrage the place premium.

\section{Trade: Stolper-Samuelson Effects}

Next, we investigate the role that trade plays in narrowing the US-Mexico wage gap. One way to evaluate the effect of trade on wage convergence is to focus on changes across different education groups. Specifically, the neoclassical trade theories that predict factor price equalization imply that the wages of less-educated workers would rise in Mexico and fall in the United States. Wages should therefore converge for less-educated workers but possibly diverge for more educated workers as predicted by Stolper-Samuelson.

We begin with Figure 6, which shows mean wage differentials for the two highest and two lowest education groups in the survey data. Wage differentials for less-educated workers are higher than for more educated workers, which is consistent with Mexico being a less-educatedworker-abundant country. The time trends for the two groups, however, are very similar. Therefore, there is little evidence of convergence in less educated groups nor of divergence in more educated groups. ${ }^{19}$

\footnotetext{
${ }^{17}$ This is not reported but is available upon request.

18 To see this note that $\frac{-2.08}{-0.307} \approx 7$.

${ }^{19}$ It is interesting, however, that during the period of rising inequality in Mexico (1987-1994), we do see divergence of the less-educated groups and convergence of the more educated groups. After NAFTA, however, the differences in convergence/divergence trends are very small.
} 
Next, we now consider how the U.S. and Mexican wage distributions evolved from 1990 to 2010 for specific education groups. This will allow us to investigate the presence of StolperSamuelson effects in the census data. To do this, we compute differences in percentiles of the U.S. and Mexican wage distribution by education and year for 2000-1990 and 2010-2000. To fix ideas, we let $q(\alpha)_{k t}^{l}$ denote the $\alpha$ th percentile for education cell $k$ at year $t$ in country $l$. We then plot the difference in difference calculated as

$$
\left(q(\alpha)_{k, 2010}^{U S}-q(\alpha)_{k, 2010}^{M X}\right)-\left(q(\alpha)_{k, 2000}^{U S}-q(\alpha)_{k, 2000}^{M X}\right)
$$

and

$$
\left(q(\alpha)_{k, 2000}^{U S}-q(\alpha)_{k, 2000}^{M X}\right)-\left(q(\alpha)_{k, 1990}^{U S}-q(\alpha)_{k, 1990}^{M X}\right)
$$

as a function of $\alpha$. The first term in parentheses in each of these expressions is the wage differential at the $\alpha$ th percentile between the U.S. and Mexico in either 2010 or 2000. The second term is the same quantity but from the previous census year. The difference in the two expressions in parentheses is then the change in the cross-border differential at a particular percentile over a ten year period. At this point, we only consider three educational cells since computing percentiles is more demanding of the data than computing means; the three cells that we consider are 0-11 (no high school), 12-16 (high school) and more than 16 years of schooling (college).

In Figure 7, we plot the changes in the relative wage distributions for 2000-2010 and 2000-1990 using both samples from the Mexican census. The most striking results are in the first row, which displays 2010-2000. First, we see that at all points in the wage distribution, there was a narrowing of the cross-border differential for people with less than twelve years of schooling. The estimates indicate that the wage differential in 2010 was roughly 85 percent of what it was in 2000 in the whole sample and $80 \%$ of what it was in the urban sample. For high school and college graduates, we see convergence at the lower end of the distribution. The estimated change in the differential is negative through the $20^{\text {th }}$ percentile for the collegeeducated and the $40^{\text {th }}$ percentile for the high school-educated in the whole sample. In the urban sample, we do not see convergence for college graduates. We do, however, see convergence up 
to the $40^{\text {th }}$ percentile for high school graduates. This indicates that the wages of U.S. workers in the bottom half of the distribution became closer to their counterparts across the border in the 2000s.

Prima facie, the convergence that we see during the 2000's for less educated people and the divergence that we see for more educated people in the top end of the wage distribution is consistent with Stolper-Samuelson type effects. However, as we will see, this is most likely the consequence of factors other than US-Mexico trade liberalization.

Next, we turn to the bottom panel that displays the difference from 1990 to 2000 . In the whole sample, the figure shows no stark patterns and, overall, is not indicative of any convergence in the two wage distributions over this period. However, in the urban sample, we see some evidence of convergence among the college-educated; in particular, their wages in Mexico in 2000 were roughly 85\% of what they were in 1990. The survey data results, however, indicate that the peso crisis led to a large divergence during the mid-90's and that this may account for the lack of evidence of convergence which we see in Figure 7 for the period 19902000.

An important question to ask at this point is whether these changes are driven by Mexico catching up or the United States falling behind. To do this, we plot the change in the wage distributions in the U.S. and Mexico from 1990-2000 and 2000-2010 in Figure 8. For each Mexican sample, we display these four profiles in three graphs corresponding to the three educational cells. The panel for people with less than twelve years of schooling indicates that a large part of the convergence that we see for the less educated is a consequence of U.S. workers falling behind. Indeed, real wages in the U.S. fell about 0.12 log points at all points in the distribution over this period. In contrast, there were modest gains in Mexican wages over this period. Turning to high school graduates in the middle panel, we see that from 2000-2010, U.S. wages fell behind quite a bit, particularly, at the bottom of the distribution. Mexican wages also declined over this period but, typically, by a smaller magnitude.

There is, however, one very important difference in the behavior of the wage structure of high school graduates from 2000-2010 between the United States and Mexico. We see that the plot for the United States is increasing and that the plot for Mexico is decreasing. What this means is that the losses in the United States disproportionately hit the poor, whereas in Mexico, they disproportionately hit people towards the top of the distribution. This suggests that 
although mean wages of high school graduates may have fallen during the 2000's in both countries, inequality for this group declined in Mexico but increased in the US. Once again, this result is consistent with Stolper-Samuelson since we see opposite movements in relative wages following trade liberalization between a labor-abundant and a labor-scarce country. We must caution once again, however, that the findings in the next section will strongly indicate that this result has more to do with a third factor than with US-Mexico trade.

We now turn to the college-educated in the third row. In the whole sample, we do not see terribly strong evidence of either Americans falling behind or Mexicans catching up during either the 1990's or the 2000's. The results, however, are starker in the urban sample. The wages of the college-educated in Mexico declined between 2000 and 2010 by roughly $10 \%$. We do, however, see that between 1990 and 2000 Mexican wage growth was over 10\% larger than in the U.S. at most points in the wage distribution. This suggests that the evidence for convergence that we saw in Figure 7 for the college-educated between 1990 and 2000 was due to gains in Mexico.

\section{FDI: Border Effects}

We now look into the possible impact of FDI on the wage differential by focusing on border effects. The main idea behind this exercise is that the border region of Mexico has traditionally received the bulk of FDI in Mexico. In addition, Figure 1 showed that the peso crisis of 1994 may confound our ability to detect any convergence during the 1990's that may have occurred. Because we will estimate a "triple diff" variant of equations (5a) and (5b) with the third difference being between the border and the interior and because the crisis impacted the entirety of Mexico, this third difference mitigates the bias from this confounding factor.

We begin with Figure 9, which divides the household survey data into border and interior regions. As is well known, the figure shows that wage differentials are larger for the interior than they are for the border. Smaller border differentials are consistent with a positive effect of FDI on wage convergence. The main point of the figure, however, is that the difference between the border and the interior is small relative to the overall differential. So, while FDI may contribute to wage convergence, its contribution appears to be modest.

Next, we consider a triple-difference version of the exercise from the previous subsection. Specifically, we compute 


$$
\begin{aligned}
& {\left[\left(q(\alpha)_{k, 2010}^{U S}-q(\alpha)_{k, 2010}^{M X, B}\right)-\left(q(\alpha)_{k, 2000}^{U S}-q(\alpha)_{k, 2000}^{M X, B}\right)\right]-} \\
& {\left[\left(q(\alpha)_{k, 2010}^{U S}-q(\alpha)_{k, 2010}^{M X, I}\right)-\left(q(\alpha)_{k, 2000}^{U S}-q(\alpha)_{k, 2000}^{M X, I}\right)\right]}
\end{aligned}
$$

where the superscript $B$ denotes Mexico's border region and $I$ denotes Mexico's interior. ${ }^{20}$ So, we look at how the change in the US-Mexico wage gap between 2010 and 2000 differs as we move from Mexico's border to its interior.

We report the results in Figure 10. During the period 2000-2010, we do not see any evidence that convergence was any faster along the border than in the interior. In fact, using the urban sample from the Mexican sample, we actually see that, relative to the interior, the wage differential along the border expanded from 2000 to 2010. What this may then indicate is that during the period 2000-2010 light industries may have exited Mexico’s border region thereby reducing wages there vis-à-vis the interior. Next, we see that during the period 1990-2000 that wages in Mexico's border region increased at a more rapid rate than in the interior. This is particularly the case in the urban sample. It is important to emphasize that we see large movements in wage differentials in the border area relative to the interior once we restrict the sample to more urban areas. During the 1990's, wages in these cities close to the border saw large gains relative to the rest of Mexico and this was subsequently reversed in the 2000's.

There are a few important points to take-away from Figures 9 and 10. First, the convergence that we see in the border relative to the interior in the 1990's does indeed indicate that FDI or, possibly trade, can narrow the wage differential and it suggests that the Peso Crisis is most likely behind the lack of convergence that we saw during the period 1990-2000. Second, differentials got larger in the border region by a large margin in the period 2000-2010. While we do not know the exact reason for this, Dussel, Peters, and Gallagher (2013) speculate that China's entry into the WTO was associated with a reduction of FDI into Mexico. Figure 10 is consistent with this. In addition, Autor, Dorn, and Hanson (2013) provide evidence that Chinese trade had adverse consequences for real wage growth for low skilled Americans, which suggests that the wage convergence that we showed in Figure 7 during the period 2000-2010 was not due to Stolper-Samuelson but instead a consequence of a third factor, namely, China's entry to the

\footnotetext{
${ }^{20}$ We define "border" to be all of Mexico's states that border with the United States which includes Baja California, Sonora, Chihuahua, Tamaulipas, and Coahuila. When we employ the whole sample, we use all wages from these states which include those from rural areas. When we employ the urban sample, we only use selected cities which include large border towns such as Tijuana and Juarez.
} 
WTO. Finally, while Figure 10 does indicate that FDI can narrow wage differentials, Figure 9 shows that the border effects are small so that the place premium would be intact even in the presence of large investments in Mexico.

Finally, to quantify the magnitude of these border effects, we estimate the following regression

$$
w_{i s t}^{M X}=T \tau+T * B O R D \varphi+\gamma_{i}+\gamma_{s}+\varepsilon_{i s t}
$$

where $w_{i s t}^{M X}$ is the $\log$ Mexican wage in education/age cell $i$, in Mexican state $s$ at time t. The vector $T$ contains year dummies and $T * B O R D$ is a vector of year dummies interacted with border dummies. Note that an observation is now an education/age/state/time cell whereas with the migration regressions, it was an education/age/time cell. Another important difference between these regressions and the migration regressions is that the migration regressions used nine age groups to be consistent with Borjas (2003) and Mishra (2007), whereas when estimating equation (7), we did not use bins but used cells for all ages between 19 and 63.

We estimate this equation separately using weights from the Mexican census and the U.S. census as well as without any weights. Using these different weighting schemes allows us to carry out something akin to the Oaxaca decomposition. For example, estimating border effects using weights from the U.S. Census allows us to gain some insights into what the effects of FDI on Mexican wages would be if Mexico’s demographic structure was more like that of the United States.

The results are reported in Table 6 . The main effects can be seen by differencing the interactions of the year and border dummies across subsequent years. We see that from 1990 to 2000, Mexican wages in states bordering the United States gained between $4.7 \%$ and $7.5 \%$ relative to the interior. These estimates are remarkably stable across samples and weighting schemes. If we use a US-Mexico differential of eight (or 2.08 log-points) as we did in the previous subsection, the border effects during the 90's constitute about a 2-3.5\% narrowing of the differential. Once again, this is not trivial but not nearly enough to achieve absolute wage convergence.

On the other hand, we see very strong declines in real wages over the period 2000-2010. When we employ the weights from the Mexican Census, the estimate is $-18.7 \%$ when we use the 
entire sample and $-17.3 \%$ when we use urban Mexicans. Using the U.S. weights in columns (2) and (5) attenuates these estimates; they become $-14.0 \%$ and $-14.1 \%$ in the entire and urban samples, respectively. If relatively less educated Mexicans were the most adversely affected in the 2000's then using U.S. weights should understate these effects in the estimation. While the estimates in this table are by no means the final word, they are (once again) very much consistent with a story in which wage gains in the 1990s were subsequently reversed in the 2000s. In any case, there is little to no evidence of wage convergence.

\section{Conclusion}

The significant and well documented “place premium” across countries could be a function of productivity, trade barriers, investment barriers, barriers to migration, or other causes. We use matched survey and census data from Mexico and the United States to evaluate the stability of the place premium over time in an environment of significantly increasing trade, investment, and migration. Our results show that wages between the two countries diverged slightly over the 1988-2011 period. Macroeconomic fluctuations, such as the peso crisis of 1994, contributed to the divergence, but the crisis was not the only relevant factor. These findings strongly indicate that the divergence from 1988-2011 had much to do with large macroeconomic events that may have counteracted the effects of US-Mexico trade and migration. Overall, however, the place premium remained remarkably stable.

A more detailed look at our data reveals that migration, trade, and FDI may contribute to modest wage convergence, despite the overall divergence in the raw data. First, we show that migration could narrow the US-Mexico wage differential. Its impact, however, is very small relative to the overall differential. Second, we find evidence of wage movements that are consistent with Stolper-Samuelson effects: relative wages of the less-skilled fall in the United States and rise in Mexico. However, these effects are present during the period 2000-2010 where the effects of NAFTA are believed to be disrupted by Chinese trade (Dussel, Peters, and Gallagher 2013) and are also driven by a precipitous decline in real U.S. wage for low skilled workers, which has also been attributed to Chinese trade (Autor, Dorn, and Hanson 2013). This casts doubt that these relative wage movements can be attributed to US-Mexico integration.

Finally, comparing relative wage movements between Mexico’s border and interior does indicate that there was some convergence in the border region during the period 1990-2000 but 
that this was reversed subsequently in the period 2000-2010. This suggests that the lack of convergence that we see in the 1990's when we take a bird's eye view of the data was due to the Peso Crisis of 1994. It also indicates that NAFTA may have, indeed, brought about some degree of wage convergence but that this was then reversed during the 2000's possibly because of China's entry into the WTO. The magnitude of these border effects, however, is very modest when compared to the overall wage differential.

We conclude that, although migration, commercial integration, and FDI may narrow the US-Mexico wage gap, their effects appear to be modest. Indeed, in the face of a large d egree of economic integration, the US-Mexico place premium has remained remarkably stable and we hope to explore other possible explanations in future work. This suggests that the international wage differences are the consequence of something other than trade, FDI, and migration barriers. Productivity differences may be one explanation, as indicated by Kennan (2013), but our results suggest opportunities for future research. 


\section{Appendix: Alternative Wage Measurements}

In the paper, we convert Mexican wages to 1990 dollars by, first, converting the wage to U.S. dollars using the nominal exchange rate for that year and then by deflating the wage to 1990 U.S. dollars using the U.S. CPI. An alternative (and equally viable) procedure would have been to deflate the Mexican wages to 1990 pesos using the Mexican CPI and then converting the wage to 1990 dollars using the nominal exchange rate from 1990. We call the wage that results from the former method MX Wage 1 and the wage that results from the second method MX Wage 2.

The comparisons of $M X$ Wage1 and MX Wage2 using the census data are reported in Table A1. The comparison of the mean value across cohorts of the two measures over time are shown in Figure A1. As can be seen, the wages are very similar using the two methods of comparison. The raw correlation between the two in the census data is 0.9985 and 0.6936 in the household data indicating that it makes little difference if we use $M X$ Wage 1 or $M X$ Wage 2.

Figure A1: Comparing Two Deflating Measures in the Household Data

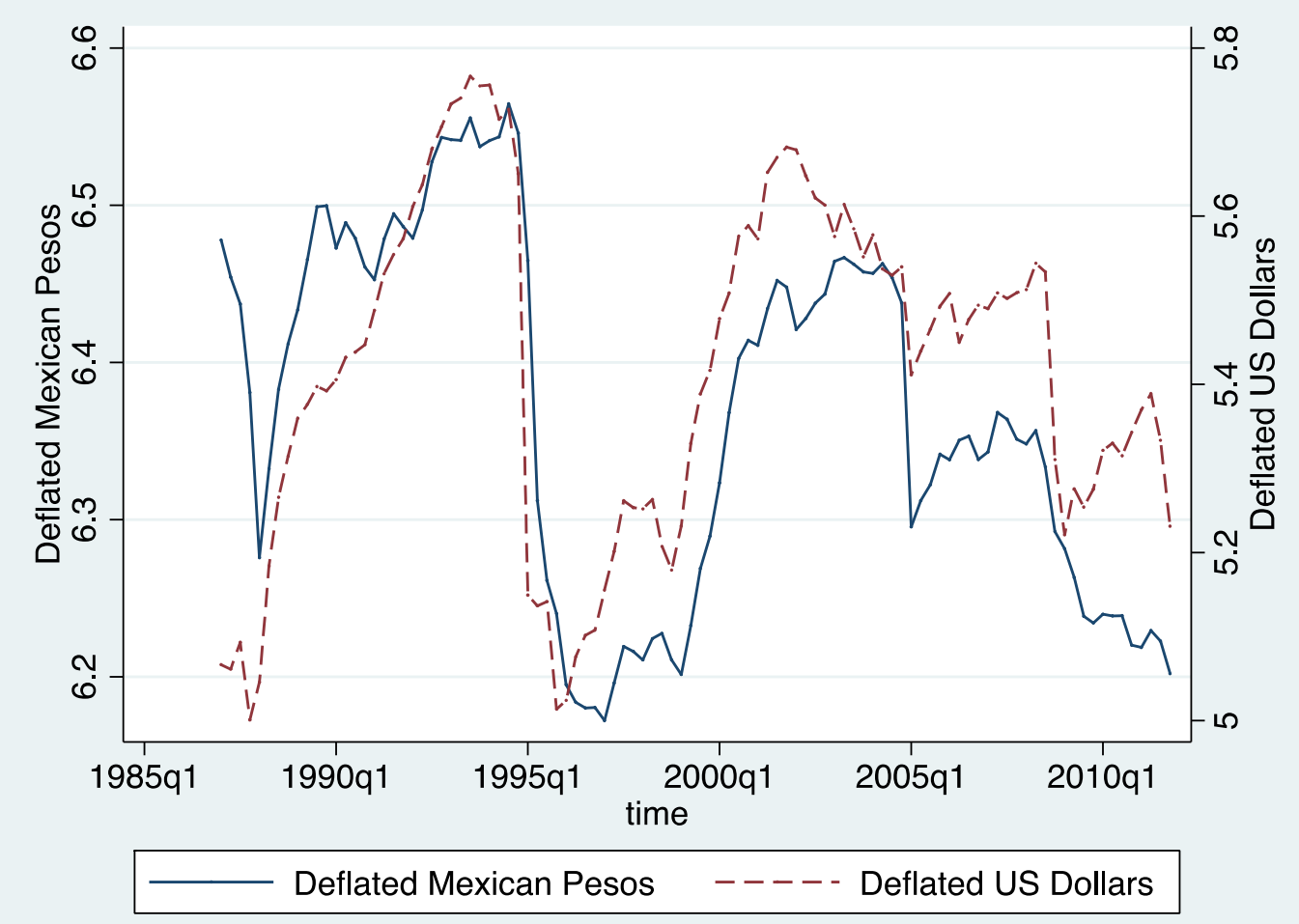

Notes: The Deflated Mexican Pesos is the mean of the log of the Mexican monthly earnings deflated by the Mexican price index. The Deflated U.S. Dollars is the dollar value of Mexican monthly earnings deflated by the U.S. CPI $(1990=1)$. 


\section{References}

Autor, David H., David Dorn, and Gordon H. Hanson (2013). “The China Syndrome: Local Labor Market Effects of Import Competition in the United States”. American Economic Review, 103(6): 2121-2168.

Banco de Mexico (2013). “Exchange rate, Pesos per U.S. dollars (Daily).” Retrieved from http://www.banxico.org.mx/SieInternet/consultarDirectorioInternetAction.do?accion=con sultarCuadro\&idCuadro $=$ CF102\&sector $=6 \&$ locale $=$ en

Borjas, George J. (2003). “The Labor Demand Curve Is Downward Sloping: Reexamining the Impact of Immigration on the Labor Market”. The Quarterly Journal of Economics, 118(4): 1335-1374.

Brezis, Elise \& Paul Krugman, 1996. "Immigration, Investment, and Real Wages," Journal of Population Economics, 9(1): 83-93, February.

Brown, Drusilla (1992). “The Impact of a North American Free Trade Area: Applied General Equilibrium Trade Models” in Lustig, Nora, Barry P. Bosworth, Robert Z. Lawrence (eds.) North American Free Trade: Assessing the Impact, The Brookings Institution, Washington D.C.

Card, David (1990). “The Impact of the Mariel Boatlift on the Miami Labor Market”. Industrial and Labor Relations Review, 43(2): 245-247.

Card, David (2001). “Immigrant Inflows, Native Outflows and the Local Labor Market Impacts of Higher Immigration”. Journal of Labor Economics, 19(1): 22-64.

Bureau of Labor Statistics. Consumer Price Index. Retrieved May 112013. http://www.bls.gov/cpi/

Chiquiar, Daniel (2001). “Regional Implications of Mexico’s Trade Liberalization”, Mimeo UCSD.

Chiquiar, Daniel and Gordon H. Hanson (2005). "Internal Migration, Self-Selection and the Distribution of Wages: Evidence from Mexico and the United States”. Journal of Political Economy, 113(2): 239-281.

Clemens, Michael, Claudio Montenegro, and Lant Pritchett (2008). “The Place Premium: Wage Differences For Identical Workers Across the U.S. Border”. World Bank Policy Research Working Paper, No. 4671.

Davis, Donald and Prachi Mishra (2007). "Stopler-Samuelson is Dead: And Other Crimes of Both Theory and Data”, Globalization and Poverty, ed. by A. Harrison. University of Chicago Press, Chicago, IL

Deaton, Angus (1985). "Panel data from time series of cross sections”. Journal of Econometrics 30(1): 109-126.

Deaton, Angus (1997). “The Analysis of Household Surveys: A Microeconomic Approach to Development Policy”. Johns Hopkins University Press: Baltimore.

Dussel Peters, Enrique and Kevin P. Gallagher (2013). "NAFTA’s Uninvited Guest: China and the Disintegration of North American Trade”. Cepel Review, 110(August): 83-108.

Elsner, Benjamin (2013a). “Does Emigration Benefit the Stayers? Evidence from EU Enlargement”. Journal of Population Economics, 26(2): 531-553.

Elsner, Benjamin (2013b). “Emigration and Wages: The EU Enlargement Experiment”. Journal of International Economics, 91(1): 154-63. 
Giovanni, Julian, Andrei A. Levchenko, and Frencesc Ortega (2015) “A Global View of CrossBorder Migration” Journal of the European Economic Association February 2015 13(1):168-202.

Goldberg, Pinelopi K., and Nina, Pavcnik (2007). “Distributional Effects of Globalization in Developing Countries”. Journal of Economic Literature, 45(1): 39-82.

Hanson, Gordon H.(1996). “Localization Economies, Vertical Organization, and Trade”. American Economic Review, 86(5): 1266-1278.

Hanson, Gordon H.(1997). "Increasing Returns, Trade, and the Regional Structure of Wages”. Economic Journal, 107(440): 113-133.

Hanson, Gordon H. (2003). "What Has Happened to Wages in Mexico Since NAFTA? Implications for Hemispheric Free Trade”. Working Paper Series, No. 9563

Hanson, Gordon H. (2010). “Why Isn’t Mexico Rich?” Journal of Economic Literature, 48(4): 987-1004.

Kennan, John (2013). "Open Borders," Review of Economic Dynamics, Elsevier for the Society for Economic Dynamics, 16(2): 1-13

Lustig, Nora, Luis F. Lopez-Calva, and Eduardo Ortiz-Juarez (2012) “Declining Inequality in Latin America in the 2000s: The Cases of Argentina, Brazil, and Mexico”, Center for Global Development, Working Paper No.307

Mishra, Prachi. (2007). "Emigration and wages in source countries: Evidence from Mexico”. Journal of Development Economics, 82(1): 180-199.

Minnesota Population Center. Integrated Public Use Microdata Series, International: Version 6.3 [Machine-readable database]. Minneapolis: University of Minnesota, 2014.

Office of the United States Trade Representative. Mexico. Retrieved April 82013. http://www.ustr.gov/countries-regions/americas/mexico

Perron, Pierre and Xiaokang Zhu (2005) "Structural Breaks with Deterministic and Stochastic Trends”. Journal of Econometrics, 129(1-2): 65-119

Roberts, Bryan, Gordon Hanson, Derekh Cornwell, and Scott Borger (2010) “An Analysis of Migrant Smuggling Costs along the Southwest Border” Department of Homeland Security Office of Immigration Studies, Working Paper, November. https://www.dhs.gov/xlibrary/assets/statistics/publications/ois-smuggling-wp.pdf.

Robertson, Raymond. (2000). "Wage Shocks and North American Labor-Market Integration”. American Economic Review, 90(4): 742-764.

Robertson, Raymond (2005) "Has NAFTA Increased Labor Market Integration between the United States and Mexico?”. The World Bank Economic Review, 19(3): 425-448.

Robertson, Raymond; Kumar, Anil; Dutkowsky, Donald (2009) "Purchasing Power Parity an Aggregation Bias in a Developing Country: The Case of Mexico”. Journal of Development Economics, 90(2): 237-243.

Steven, Ruggles, J. Trent Alexander, Katie Genadek, Ronald Goeken, Matthew B. Schroeder, and Matthew Sobek (2010). Integrated Public Use Microdata Series: Version 5.0 [Machine-readable database]. Minneapolis: University of Minnesota

Schott, Peter K. (2003). "One Size Fits All? Heckscher-Ohlin Specialization in Global Production”. American Economic Review, 93(3): 686-708.

United States Census Bureau. Trade in Goods with Mexico. Retrieved April 82013. http://www.census.gov/foreign-trade/balance/c2010.html 
Vogelsang, Timothy J. and Pierre Perron (1998) “Additional Tests for a Unit Root Allowing for a Break in the Trend Function at an Unknown Time". International Economic Review, 39(4): 1073-1100.

Zong, Jie and Jeanne Batalova (2014) “Mexican Immigrants in the United States” Migration Policy Institute, http://www.migrationpolicy.org/article/mexican-immigrants-unitedstates. 
Table 1: Summary Statistics, Survey Data

\begin{tabular}{|c|c|c|c|c|}
\hline & \multicolumn{4}{|c|}{ United States } \\
\hline & 1988-1994 & $1995-2002$ & $2003-2007$ & 2008-2011 \\
\hline \multirow[t]{2}{*}{ Monthly Wage } & $\$ 2,333.31$ & $\$ 2,456.18$ & $\$ 2,502.13$ & $\$ 2,483.03$ \\
\hline & (1586.01) & (1805.99) & (1704.53) & (1694.77) \\
\hline \multirow[t]{2}{*}{ Hourly Wage } & $\$ 12.66$ & $\$ 13.26$ & $\$ 13.63$ & $\$ 13.71$ \\
\hline & (8.30) & (9.27) & (10.12) & (10.39) \\
\hline \multirow[t]{2}{*}{ Age } & 37.01 & 37.44 & 38.76 & 39.85 \\
\hline & (11.54) & (11.26) & (11.26) & (11.75) \\
\hline \multicolumn{5}{|l|}{ Education } \\
\hline $0-4$ & $0.93 \%$ & $0.84 \%$ & $0.88 \%$ & $0.75 \%$ \\
\hline $5-8$ & $3.40 \%$ & $3.01 \%$ & $2.97 \%$ & $2.53 \%$ \\
\hline $9-12$ & $44.18 \%$ & $42.15 \%$ & $41.46 \%$ & $39.47 \%$ \\
\hline $13-16$ & $40.89 \%$ & $41.53 \%$ & $40.23 \%$ & $41.85 \%$ \\
\hline$>16$ & $10.61 \%$ & $12.46 \%$ & $14.46 \%$ & $15.39 \%$ \\
\hline \multirow[t]{3}{*}{$\begin{array}{l}\text { Mean N per } \\
\text { quarter }\end{array}$} & $21,155.89$ & $19,393.91$ & $20,960.35$ & $19,667.75$ \\
\hline & \multicolumn{4}{|c|}{ Mexico } \\
\hline & 1988-1994 & 1995-2002 & 2003-2007 & 2008-2011 \\
\hline \multirow[t]{2}{*}{ Monthly Wage } & $\$ 344.75$ & $\$ 303.99$ & $\$ 328.57$ & $\$ 276.13$ \\
\hline & (505.69) & $(447.68)$ & (377.09) & (300.16) \\
\hline \multirow[t]{2}{*}{ Hourly Wage } & $\$ 1.67$ & $\$ 1.47$ & $\$ 1.59$ & $\$ 1.34$ \\
\hline & $(2.45)$ & $(2.17)$ & (1.83) & $(1.45)$ \\
\hline \multirow[t]{2}{*}{ Age } & 34.91 & 35.45 & 36.79 & 37.29 \\
\hline & (11.33) & (11.25) & (11.45) & (11.60) \\
\hline \multicolumn{5}{|l|}{ Education } \\
\hline $0-4$ & $20.22 \%$ & $16.00 \%$ & $11.55 \%$ & $11.22 \%$ \\
\hline $5-8$ & $36.02 \%$ & $33.60 \%$ & $28.46 \%$ & $25.14 \%$ \\
\hline $9-12$ & $27.34 \%$ & $32.62 \%$ & $40.41 \%$ & $42.32 \%$ \\
\hline $13-16$ & $15.44 \%$ & $16.79 \%$ & $18.29 \%$ & $19.99 \%$ \\
\hline$>16$ & $0.97 \%$ & $0.98 \%$ & $1.29 \%$ & $1.33 \%$ \\
\hline $\begin{array}{l}\text { Mean N per } \\
\text { quarter }\end{array}$ & $32,906.07$ & $41,572.53$ & $30,509.20$ & $27,207.75$ \\
\hline
\end{tabular}


Table 2: Descriptive Statistics, Census Data

\begin{tabular}{|c|c|c|c|}
\hline & 1990 & 2000 & 2010 \\
\hline & \multicolumn{3}{|c|}{ US } \\
\hline Hourly Wage & $\$ 14.21$ & $\$ 15.07$ & $\$ 14.98$ \\
\hline Age & $\begin{array}{c}36.83 \\
(11.59)\end{array}$ & $\begin{array}{c}(12.49) \\
38.33 \\
(11.50)\end{array}$ & $\begin{array}{c}(13.09) \\
39.61 \\
(12.27)\end{array}$ \\
\hline \multicolumn{4}{|l|}{ Education } \\
\hline $0-4$ & $1.56 \%$ & $1.56 \%$ & $1.50 \%$ \\
\hline $5-8$ & $3.26 \%$ & $3.20 \%$ & $3.01 \%$ \\
\hline $9-12$ & $37.72 \%$ & $35.42 \%$ & $32.36 \%$ \\
\hline $13-16$ & $47.99 \%$ & $49.66 \%$ & $52.07 \%$ \\
\hline$>16$ & $9.47 \%$ & $10.15 \%$ & $11.06 \%$ \\
\hline $\mathrm{N}$ & $1,982,151$ & 2,361,079 & 496,042 \\
\hline & \multicolumn{3}{|c|}{ MX - Whole Sample } \\
\hline Hourly Wage & $\begin{array}{l}\$ 1.43 \\
(1.82)\end{array}$ & $\begin{array}{l}1.55 \\
(1.92)\end{array}$ & $\begin{array}{l}1.59 \\
(1.81)\end{array}$ \\
\hline Age & $\begin{array}{c}34.79 \\
(11.20)\end{array}$ & $\begin{array}{c}35.39 \\
(11.04)\end{array}$ & $\begin{array}{c}37.10 \\
(11.38)\end{array}$ \\
\hline \multicolumn{4}{|l|}{ Education } \\
\hline $0-4$ & $29.54 \%$ & $18.50 \%$ & $11.99 \%$ \\
\hline $5-8$ & $30.01 \%$ & $27.06 \%$ & $21.78 \%$ \\
\hline $9-12$ & $27.41 \%$ & $38.24 \%$ & $45.91 \%$ \\
\hline $13-16$ & $7.09 \%$ & $9.74 \%$ & $12.32 \%$ \\
\hline$>16$ & $5.95 \%$ & $6.46 \%$ & $8.01 \%$ \\
\hline $\mathrm{N}$ & $1,264,613$ & $1,597,037$ & $1,754,953$ \\
\hline & \multicolumn{3}{|c|}{ MX - Urban Sample } \\
\hline Hourly Wage & $\$ 1.61$ & $\$ 1.77$ & $\$ 1.74$ \\
\hline & $(1.98)$ & $(2.15)$ & $(1.97)$ \\
\hline Age & $\begin{array}{c}34.59 \\
(10.97)\end{array}$ & $\begin{array}{c}35.42 \\
(10.91)\end{array}$ & $\begin{array}{c}37.46 \\
(11.35)\end{array}$ \\
\hline \multicolumn{4}{|l|}{ Education } \\
\hline $0-4$ & $18.38 \%$ & $11.15 \%$ & $7.36 \%$ \\
\hline $5-8$ & $31.00 \%$ & $25.11 \%$ & $19.02 \%$ \\
\hline $9-12$ & $33.04 \%$ & $43.92 \%$ & $49.67 \%$ \\
\hline $13-16$ & $9.73 \%$ & $12.02 \%$ & $14.75 \%$ \\
\hline$>16$ & $7.84 \%$ & $7.80 \%$ & $9.20 \%$ \\
\hline $\mathrm{N}$ & 507,068 & 538,663 & 360,515 \\
\hline
\end{tabular}

Notes: All wages are in 1990 U.S. dollars. In Mexico, the hourly wage was computed by converting wages to U.S. dollars using the exchange rate for that year and then deflating the wages using the U.S. CPI. U.S. census data were 5\% samples except for the American Community Survey sample in 2010 which was a 1\% sample. The Mexican census was a 10\% sample for all three years. In Mexico, the whole sample uses all people who meet the sample criteria described above and the urban sample uses these criteria and further restricts the sample to the metropolitan areas that are employed in the Mexican survey data. 
Table 3: Trend Analysis, Survey Data

\begin{tabular}{lccc}
\hline \hline & $(1)$ & $(2)$ & $(3)$ \\
& Time Trend & Period Controls & Joint Broken Trend \\
\hline \hline Trend & & & \\
& 0.000 & $-0.002^{* * *}$ & $-0.015^{* * *}$ \\
$1995+$ & $(0.000)$ & $(0.001)$ & $(0.001)$ \\
$\quad($ level) & & $0.300^{* * *}$ & \\
$2001+$ & $(0.027)$ & \\
$\quad($ level) & $-0.153^{* * *}$ & $0.038^{* * *}$ \\
Trend 95-01 & $(0.010)$ & $(0.002)$ \\
$\quad($ change) & & $-0.023^{* * *}$ \\
Trend 01+ & & & $(0.002)$ \\
$\quad$ change) & & & $3.633^{* * *}$ \\
Constant & & & $(0.113)$ \\
& $1.819 * * *$ & $1.959 * * *$ & \\
Observations & $(0.074)$ & $(0.105)$ & 4,500 \\
R-squared & 4,500 & 4,500 & 0.099 \\
\hline \hline
\end{tabular}

Notes: Robust standard errors in parentheses. ${ }^{* * *} \mathrm{p}<0.01,{ }^{* *} \mathrm{p}<0.05,{ }^{*} \mathrm{p}<0.1$. The trend representing post 2001 is the sum of Trend+Trend 95-01 (Change) + Trend 01+ (change), which is equal to -0.0003 with a standard error of 0.0008 (with a p-value of 0.691), which is for just about all practical purposes a tightly-estimated zero value. 
Table 4: Migration and Wage Convergence, Survey Data

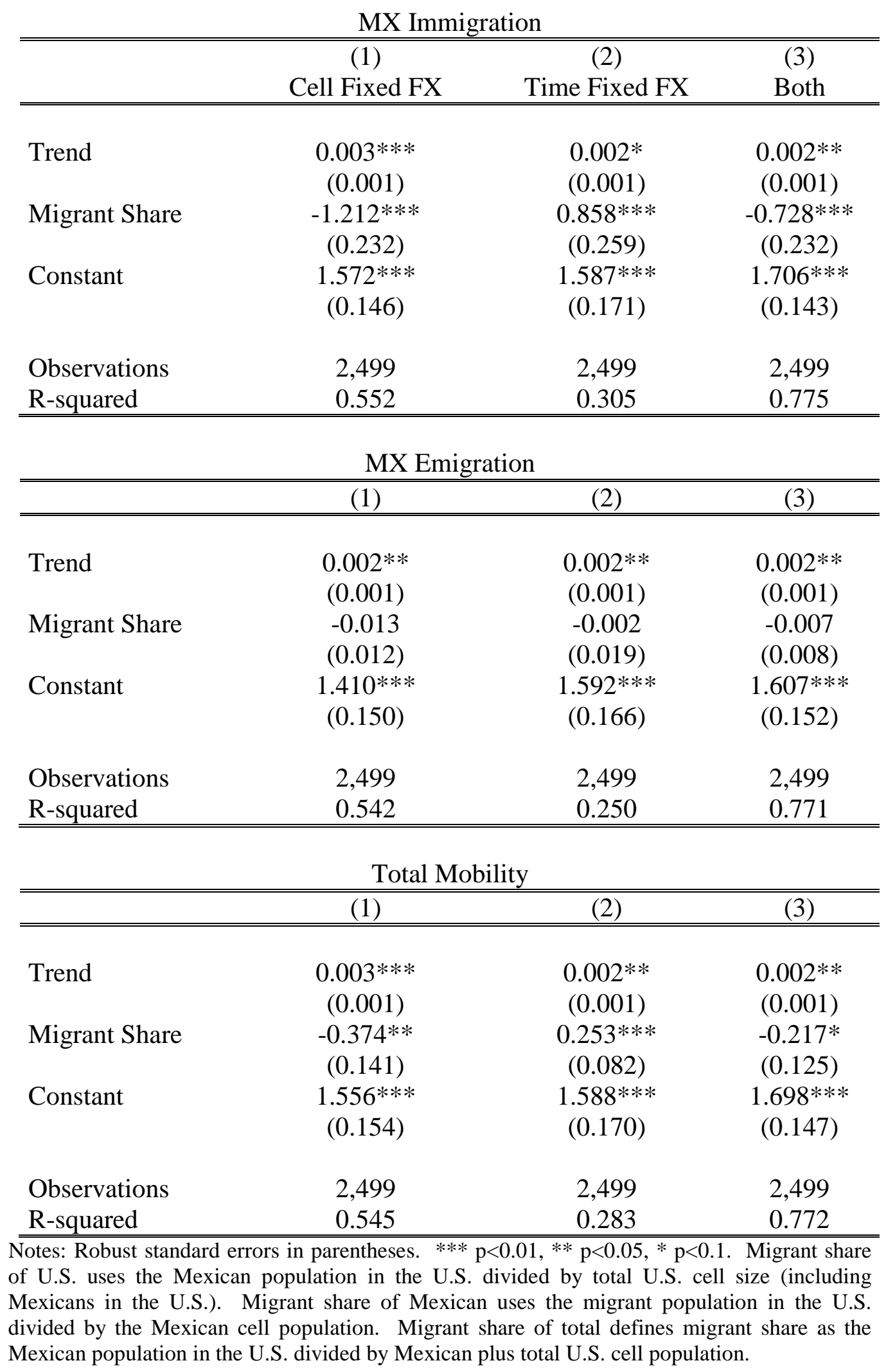


Table 5: Migration and Wage Convergence, Census Data

\begin{tabular}{|c|c|c|c|c|c|c|c|c|c|}
\hline & $(1)$ & $(2)$ & (3) & (4) & (5) & (6) & $(7)$ & $(8)$ & $(9)$ \\
\hline & \multicolumn{3}{|c|}{ Mexican Wages } & \multicolumn{3}{|c|}{ U.S. Wages } & \multicolumn{3}{|c|}{ U.S. - Mexican Differential } \\
\hline \multicolumn{10}{|c|}{ Whole Sample } \\
\hline MX Emigration & $\begin{array}{l}-0.530^{* *} \\
(0.243)\end{array}$ & & & $\begin{array}{l}-0.091 \\
(0.223)\end{array}$ & & & $\begin{array}{l}0.836^{* *} \\
(0.403)\end{array}$ & & \\
\hline MX Immigration & & $\begin{array}{c}-0.323^{* * *} \\
(0.081)\end{array}$ & & & $\begin{array}{c}-0.523^{* * *} \\
(0.096)\end{array}$ & & & $\begin{array}{c}0.023 \\
(0.146)\end{array}$ & \\
\hline Total Mobility & & & $\begin{array}{c}-1.200^{* * *} \\
(0.307)\end{array}$ & & & $\begin{array}{c}-1.535^{* * *} \\
(0.307)\end{array}$ & & & $\begin{array}{c}0.282 \\
(0.507)\end{array}$ \\
\hline Weights & MX & MX & $\mathrm{MX}$ & US & US & US & MX+US & MX+US & $\mathrm{MX}+\mathrm{US}$ \\
\hline $\mathrm{R} 2$ & 0.9829 & 0.9840 & 0.9839 & 0.9904 & 0.9919 & 0.9922 & 0.8871 & 0.8793 & 0.8795 \\
\hline \multicolumn{10}{|c|}{ Urban Sample } \\
\hline MX Emigration & $\begin{array}{l}-0.087 \\
(0.082)\end{array}$ & & & $\begin{array}{c}-0.121 \\
(0.105)\end{array}$ & & & $\begin{array}{c}0.164 \\
(0.171)\end{array}$ & & \\
\hline MX Immigration & & $\begin{array}{c}-0.247^{* * *} \\
(0.085)\end{array}$ & & & $\begin{array}{c}-0.523^{* * *} \\
(0.096)\end{array}$ & & & $\begin{array}{l}-0.150 \\
(0.167)\end{array}$ & \\
\hline Total Mobility & & & $\begin{array}{l}-0.293^{*} \\
(0.175)\end{array}$ & & & $\begin{array}{c}-0.823^{* * *} \\
(0.166)\end{array}$ & & & $\begin{array}{l}-0.307 \\
(0.285)\end{array}$ \\
\hline Weights & MX & MX & MX & US & US & US & $\mathrm{MX}+\mathrm{US}$ & MX+US & $\mathrm{MX}+\mathrm{US}$ \\
\hline R2 & 0.9824 & 0.9831 & 0.9826 & 0.9906 & 0.9919 & 0.9919 & 0.8732 & 0.8719 & 0.8723 \\
\hline
\end{tabular}

Notes: Each group is an education/age/time cell. MX Emigration is the ratio of Mexican born people in the U.S. to the number of people in the

Mexico in the same education/age/time cell. MX Immigration is the ratio of Mexican born people in the U.S. to the number of people in the U.S. in the same education/age/time cell. Total Mobility is the ratio Mexican born people in the U.S. to the total number of people in the U.S. and Mexico in the same education/age/time cell. All estimations include year dummies and education//age fixed effects. We used 45 age/education cells per year for a total of 135 cells. ${ }^{* * *} \mathrm{p}<0.01,{ }^{* *} \mathrm{p}<0.05,{ }^{*} \mathrm{p}<0.1$ 
Table 6: Border Effects on Mexican Wages, Census Data

\begin{tabular}{|c|c|c|c|c|c|c|}
\hline & $(1)$ & $(2)$ & (3) & $(4)$ & $(5)$ & $(6)$ \\
\hline & \multicolumn{3}{|c|}{ Whole Sample } & \multicolumn{3}{|c|}{ Urban Sample } \\
\hline 2000 Dummy & $-0.016^{* * *}$ & $0.093^{* * *}$ & $0.048^{* * *}$ & -0.001 & $0.088^{\text {*** }}$ & $0.044^{* * *}$ \\
\hline & $(0.004)$ & $(0.005)$ & $(0.005)$ & $(0.008)$ & $(0.009)$ & $(0.007)$ \\
\hline 2010 Dummy & -0.003 & $0.020^{* * *}$ & $0.056^{* * *}$ & $-0.037^{* * *}$ & $-0.002^{*}$ & $0.020^{* * *}$ \\
\hline & $(0.004)$ & $(0.005)$ & $(0.004)$ & $(0.008)$ & $(0.009)$ & $(0.007)$ \\
\hline 1990 Dummy * & $-0.025^{* *}$ & -0.014 & $0.132^{* * *}$ & $0.666^{* * *}$ & $0.614^{* * * *}$ & $0.637^{* * *}$ \\
\hline Border & $(0.010)$ & $(0.015)$ & $(0.013)$ & $(0.019)$ & $(0.027)$ & $(0.024)$ \\
\hline 2000 Dummy * & $0.050^{* * *}$ & $0.033^{* *}$ & $0.190^{* * *}$ & $0.733^{* * *}$ & $0.680^{* * * *}$ & $0.709^{* * *}$ \\
\hline Border & $(0.010)$ & $(0.016)$ & $(0.012)$ & $(0.018)$ & $(0.027)$ & $(0.023)$ \\
\hline 2010 Dummy * & $-0.137^{* * *}$ & $-0.107^{* * *}$ & 0.026 & $0.560^{* * *}$ & $0.539^{* * * *}$ & $0.564^{* * *}$ \\
\hline Border & $(0.011)$ & $(0.016)$ & $(0.013)$ & $(0.020)$ & $(0.030)$ & $(0.025)$ \\
\hline \multicolumn{7}{|l|}{$\begin{array}{c}\text { \% Change at } \\
\text { Border }\end{array}$} \\
\hline 2000-1990 & $7.5 \%$ & $4.7 \%$ & $5.8 \%$ & $6.7 \%$ & $6.6 \%$ & $7.2 \%$ \\
\hline $2010-2000$ & $-18.7 \%$ & $-14.0 \%$ & $-16.4 \%$ & $-17.3 \%$ & $-14.1 \%$ & $-14.5 \%$ \\
\hline Weights & MX & US & NONE & MX & US & NONE \\
\hline $\mathrm{R} 2$ & 0.8998 & 0.8017 & 0.8506 & 0.8796 & 0.7569 & 0.8027 \\
\hline $\begin{array}{l}\text { Number of } \\
\text { Groups }\end{array}$ & 21192 & 21192 & 21192 & 9834 & 9834 & 9834 \\
\hline
\end{tabular}

Notes: Each group is an education/age/time/state cell. All estimations include age*education dummies as well as year dummies and Mexican state dummies. *** $\mathrm{p}<0.01,{ }^{* *} \mathrm{p}<0.05,{ }^{*} \mathrm{p}<0.1$ 
Table A1: Alternative Wage Measurements in the Mexican Census

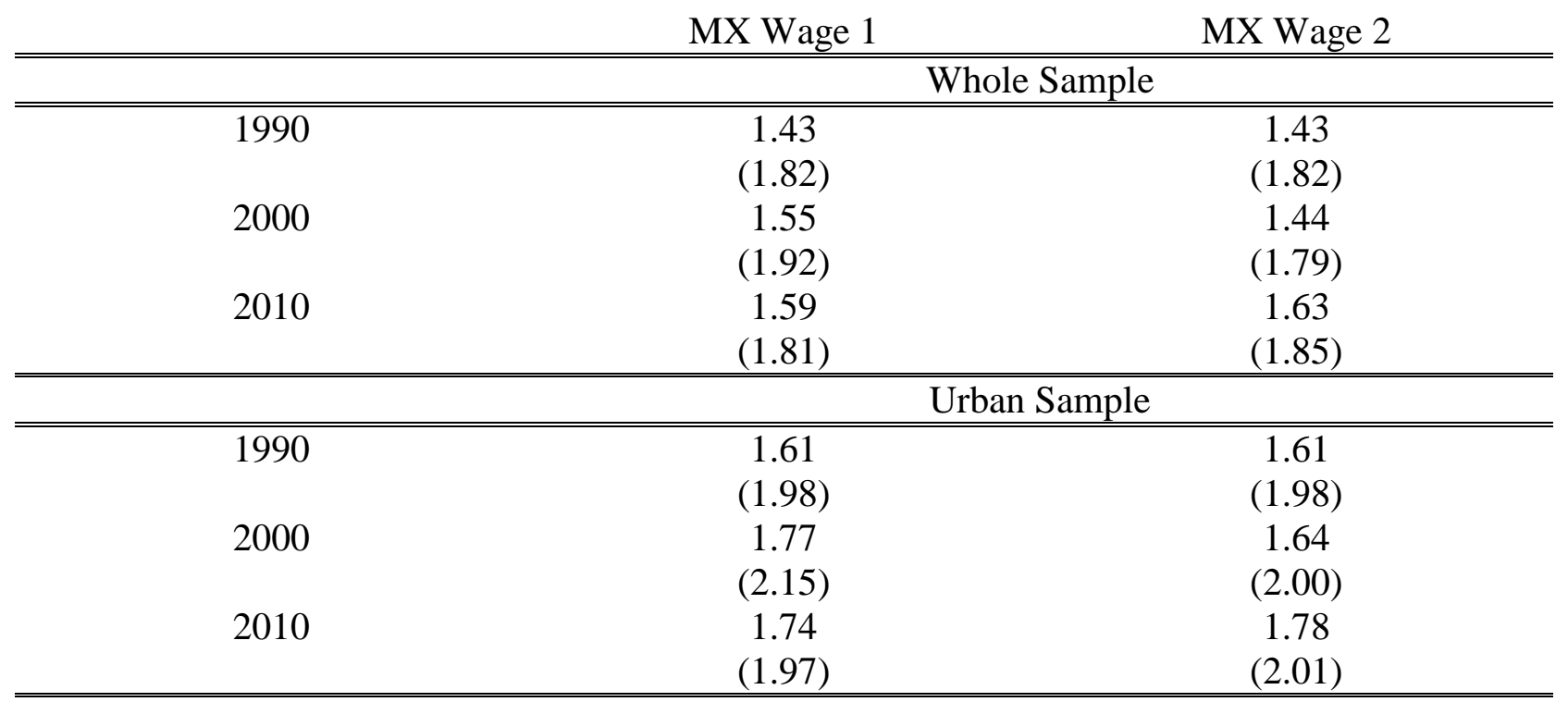

Notes: Each cell reports the mean and the standard deviation in parentheses. MX Wage 1 was obtained by converting the wage in pesos to U.S. dollars using the nominal exchange rate for that year and we then delated these wages to 1990 U.S. dollars using U.S. CPI. MX Wage 2 was obtained by deflating the wage to 1990 pesos using the Mexican CPI and then converting it to 1990 U.S. dollars using the 1990 exchange rate. 
Figure 1: Median, Maximum, and Minimum Differentials across Cells and Time

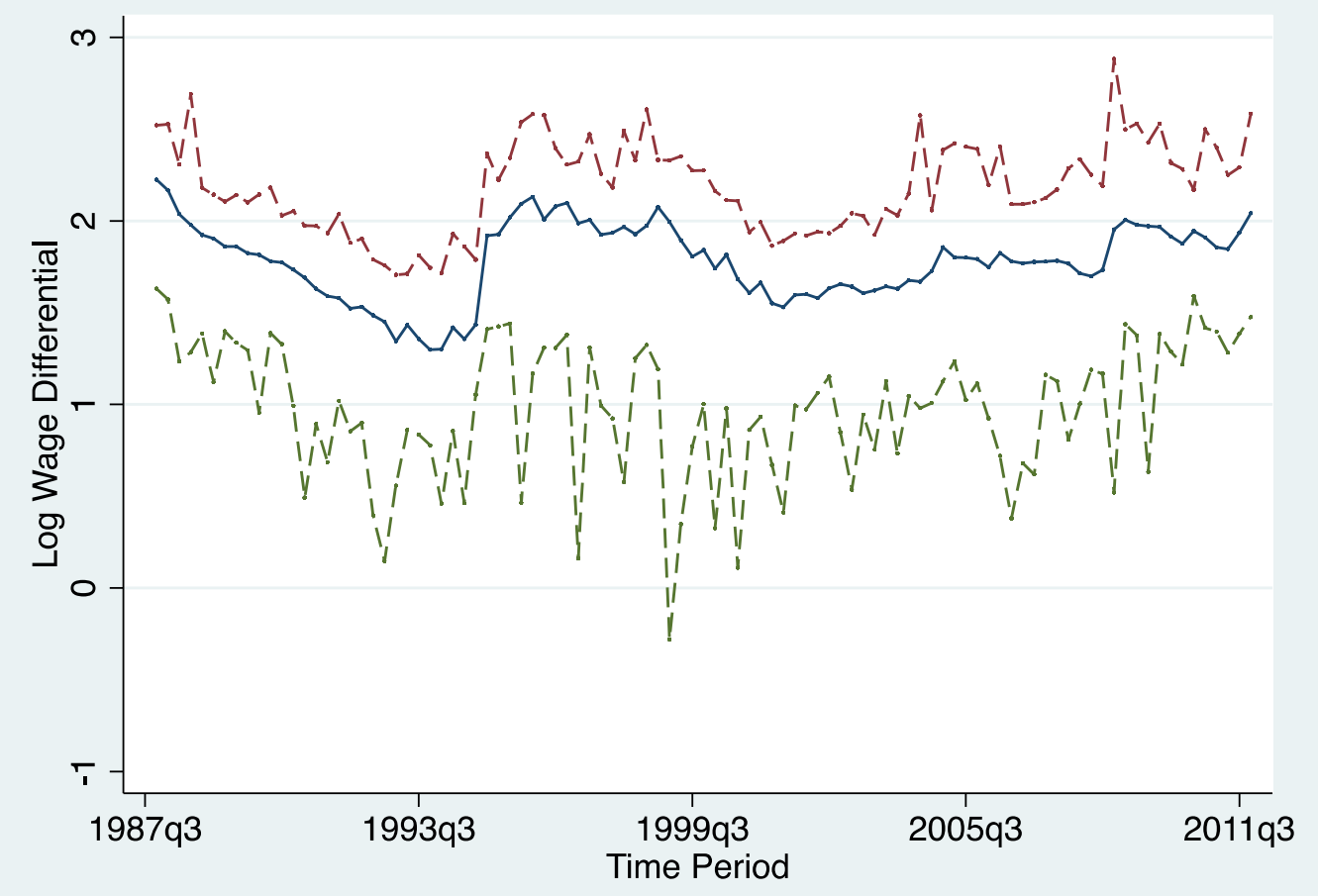

Notes: The solid line represents the median of the log difference in the U.S.-Mexican matched cell monthly earnings. Both Mexican and U.S. earnings are in real (1990) dollars, calculated by first transforming Mexican earnings into dollars using the contemporaneous nominal exchange rate and then adjusting the Mexican earnings with the U.S. CPI $(1990=1)$. 
Figure 2: Mean Wage Differential and Trend Break Statistic

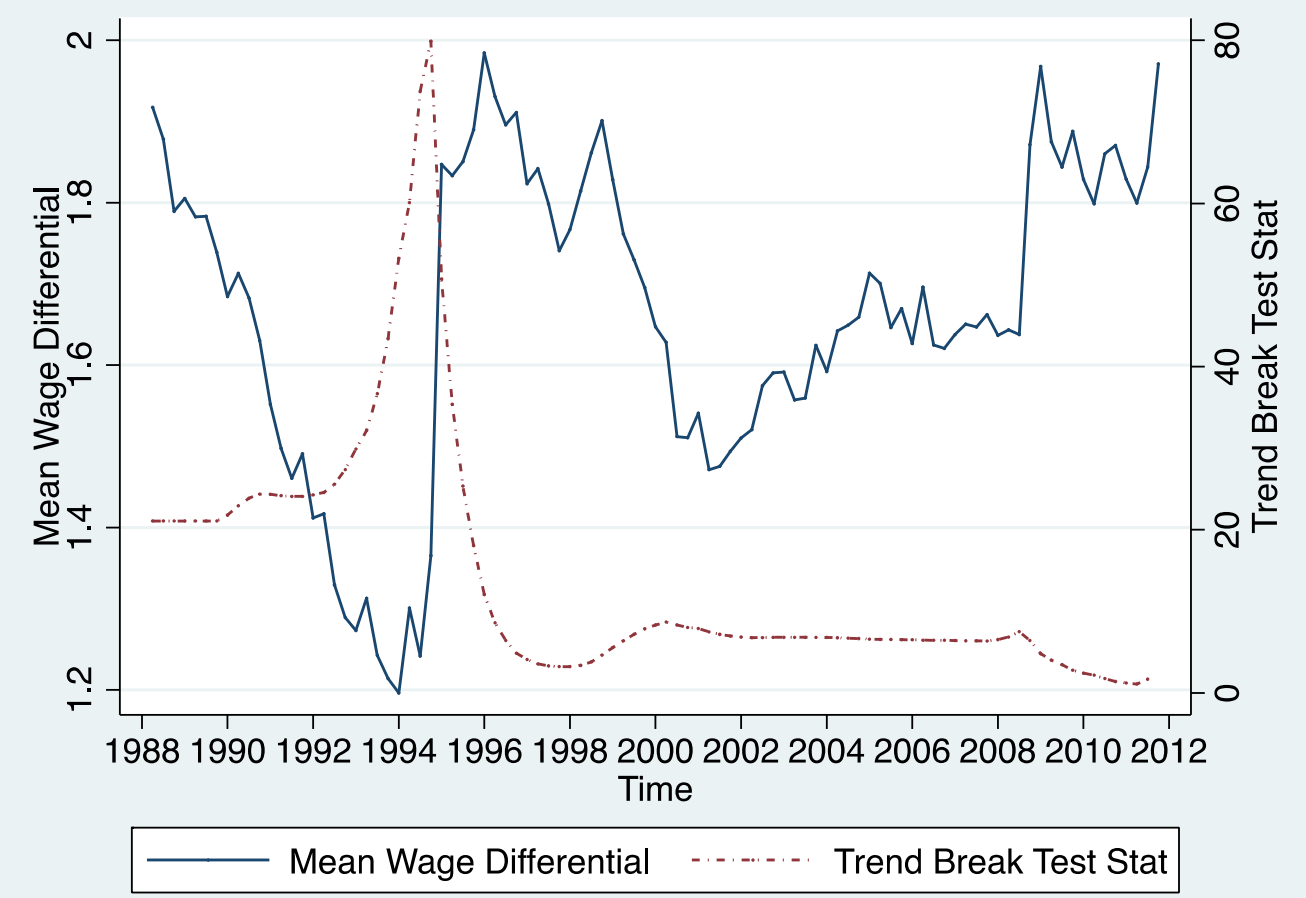

Notes: The trend break test statistic is test 2a from Vogelsang and Perron (1998), which is an additive outlier test for an unknown break. Note that peaks occur at the peso crisis (December 1994) and in 2001, which marks both a U.S. recession and the Chinese entrance into the World Trade Organization. 
Figure 3: Percentage of Mexican-born Workers in the U.S. by Age and Education, Household Surveys

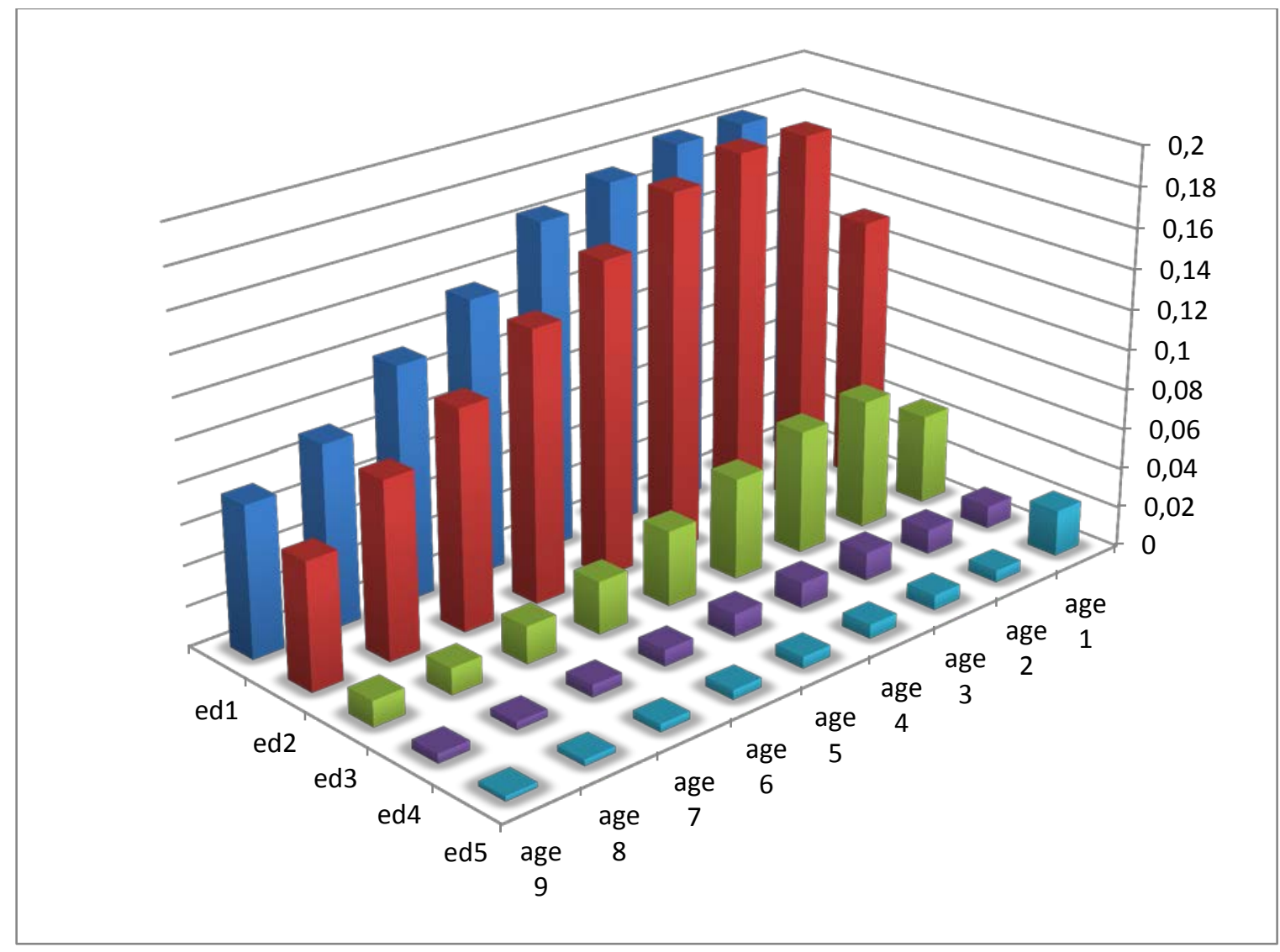

Notes: The vertical axis is the migrant share of each cell calculated as the number of Mexicans in the U.S. divided by the sum of number of Mexicans in Mexico plus the number of Mexicans in the U.S. plus the number of nonMexicans in the U.S. (again, in each cell). The first age group includes workers aged 19-23 years old; the second includes workers aged 24-28, the third those aged 29-33, and so forth. The first education group includes adults with 0-4 years of education; the second includes adults with5-8 years of education; the next comprise those with 9-12 1316 , and finally more than 16 years of education. 
Figure 4: Percentage of Mexican-born Workers in the U.S. by Age and Education, Census Data

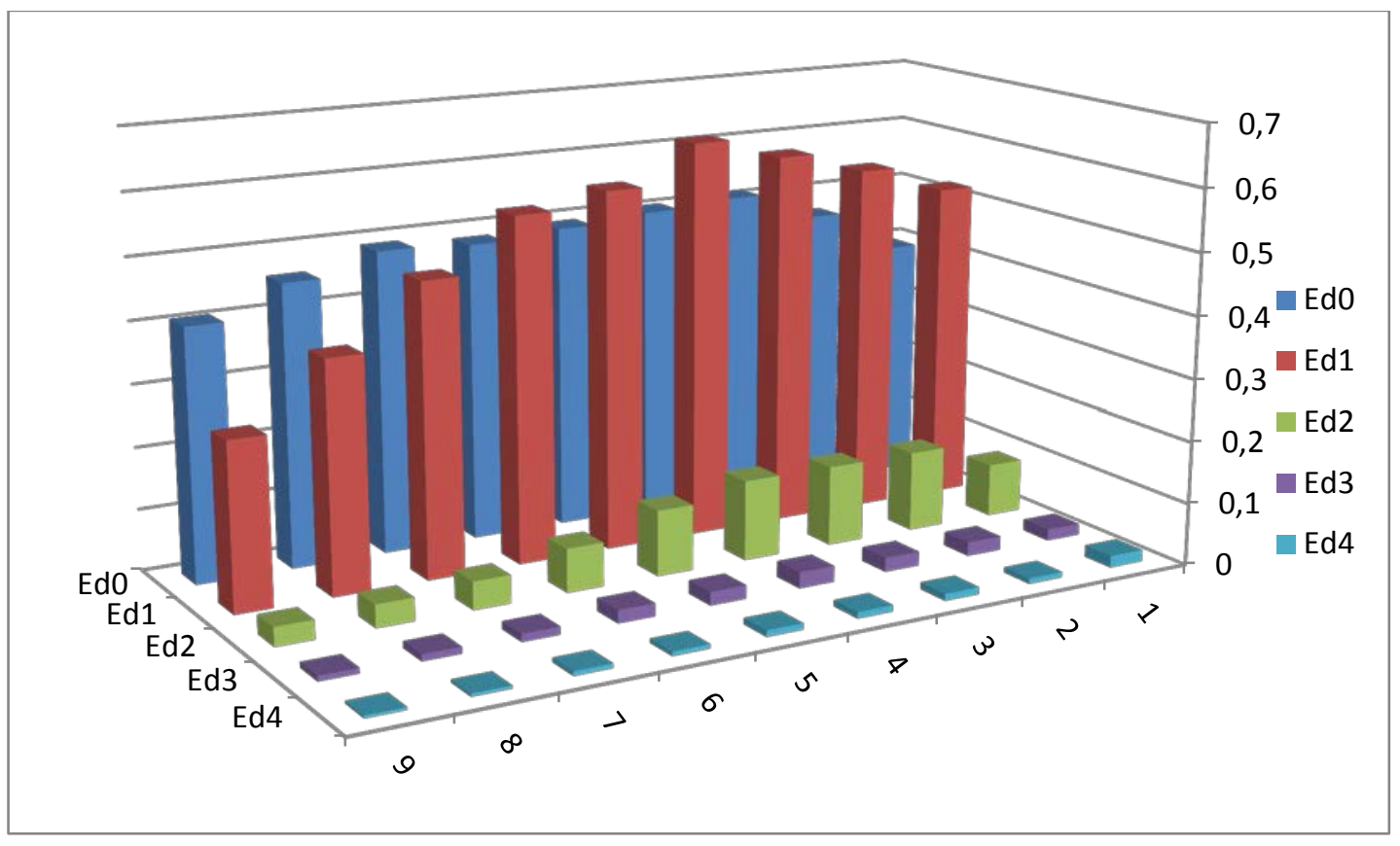

Notes: The first age group includes workers aged 19-23 years old; the second includes workers aged 24-28, the third those aged 29-33, and so forth. The first education group includes adults with 0-4 years of education; the second includes adults with 5-8 years of education; the next comprise those with 9-12, 13-16, and finally 17 or more years of education. 
Figure 5: Mean Wage Differentials by Age, Census Data

MX - Whole Sample
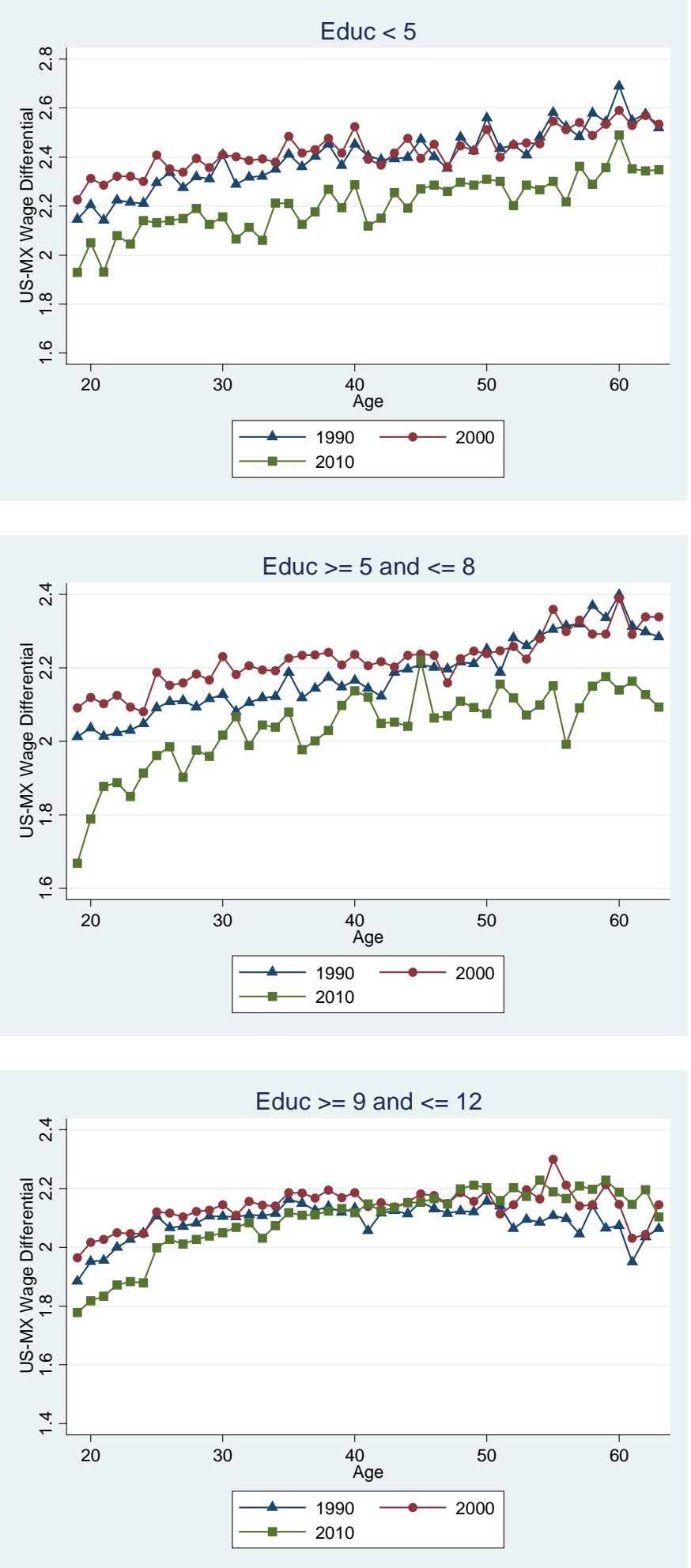

MX - Urban Sample
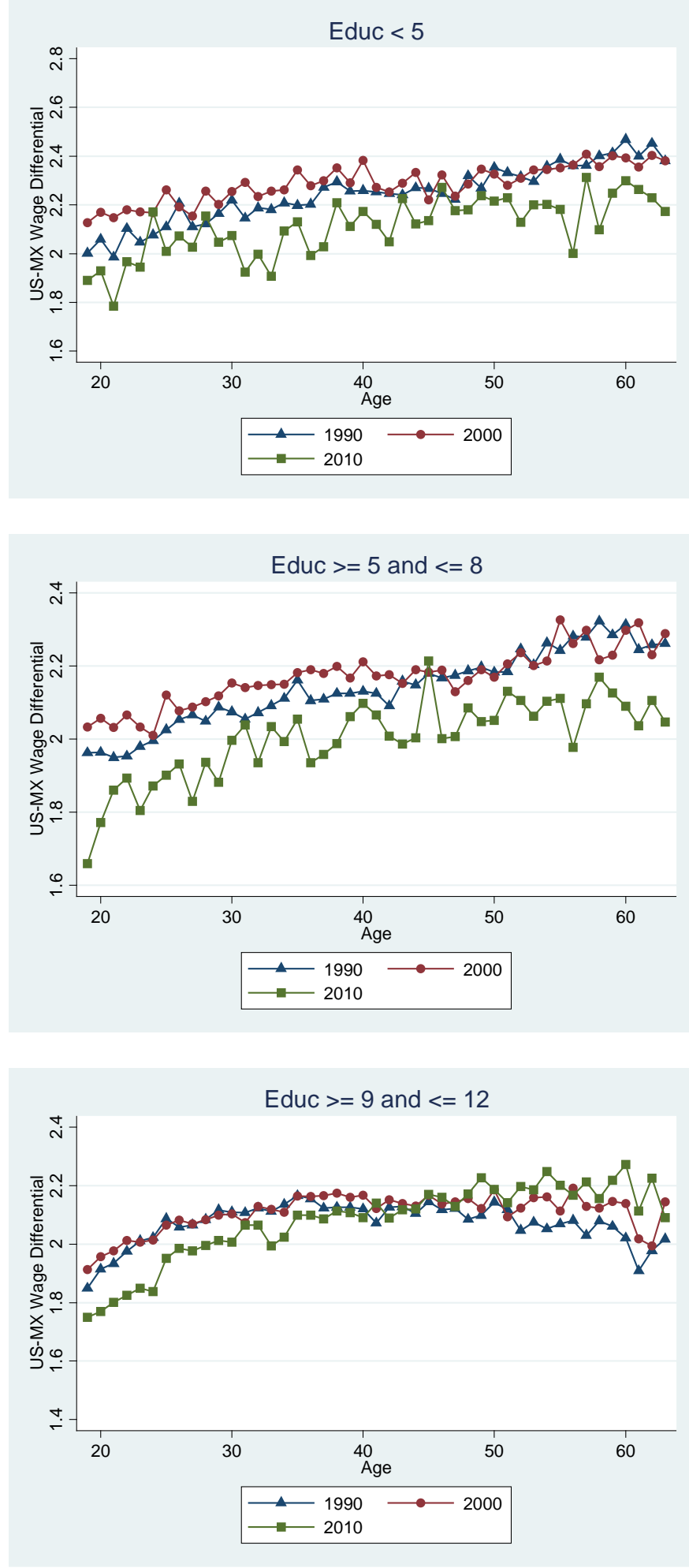

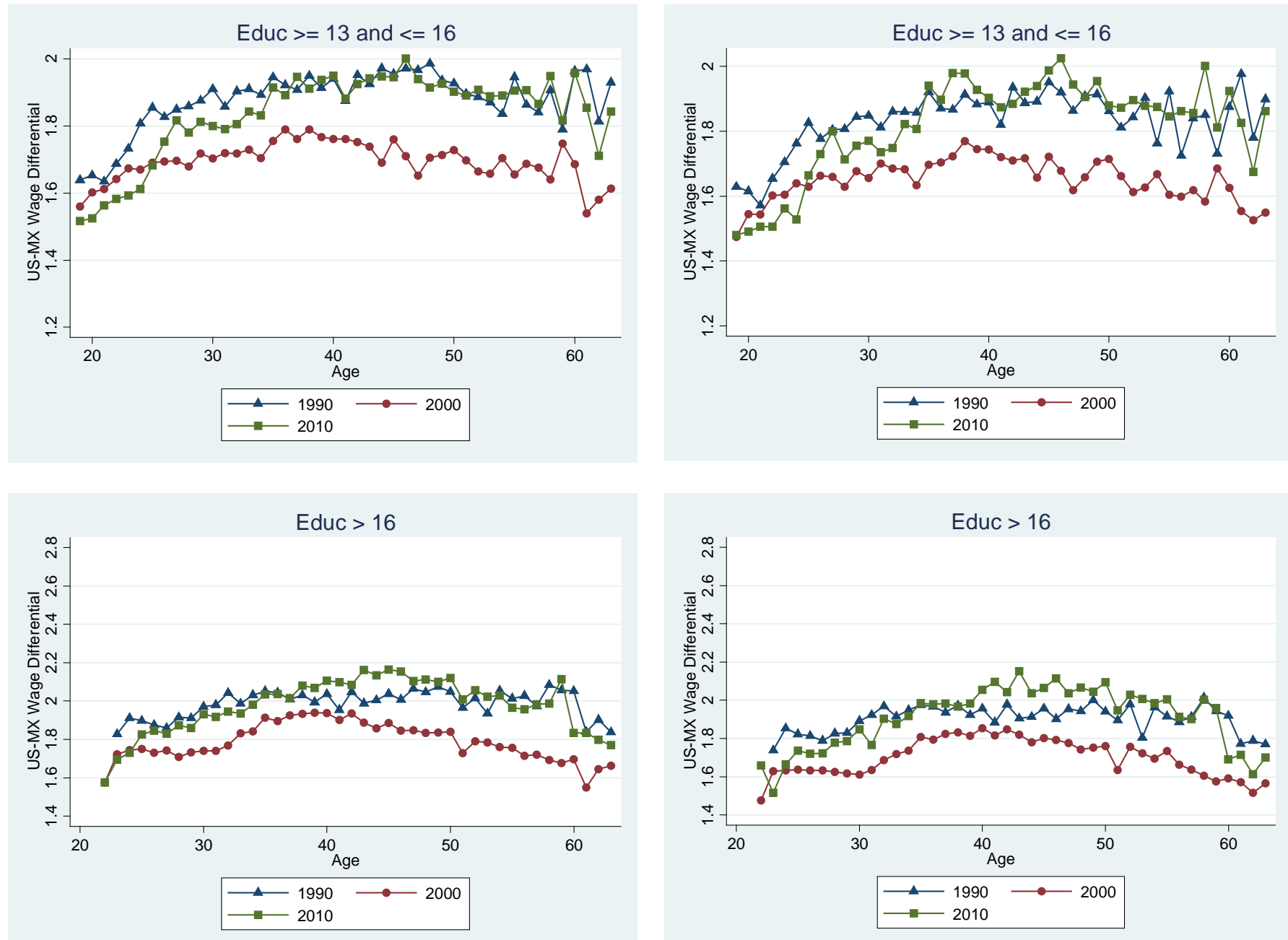
Figure 6: Wage differentials by Education Level

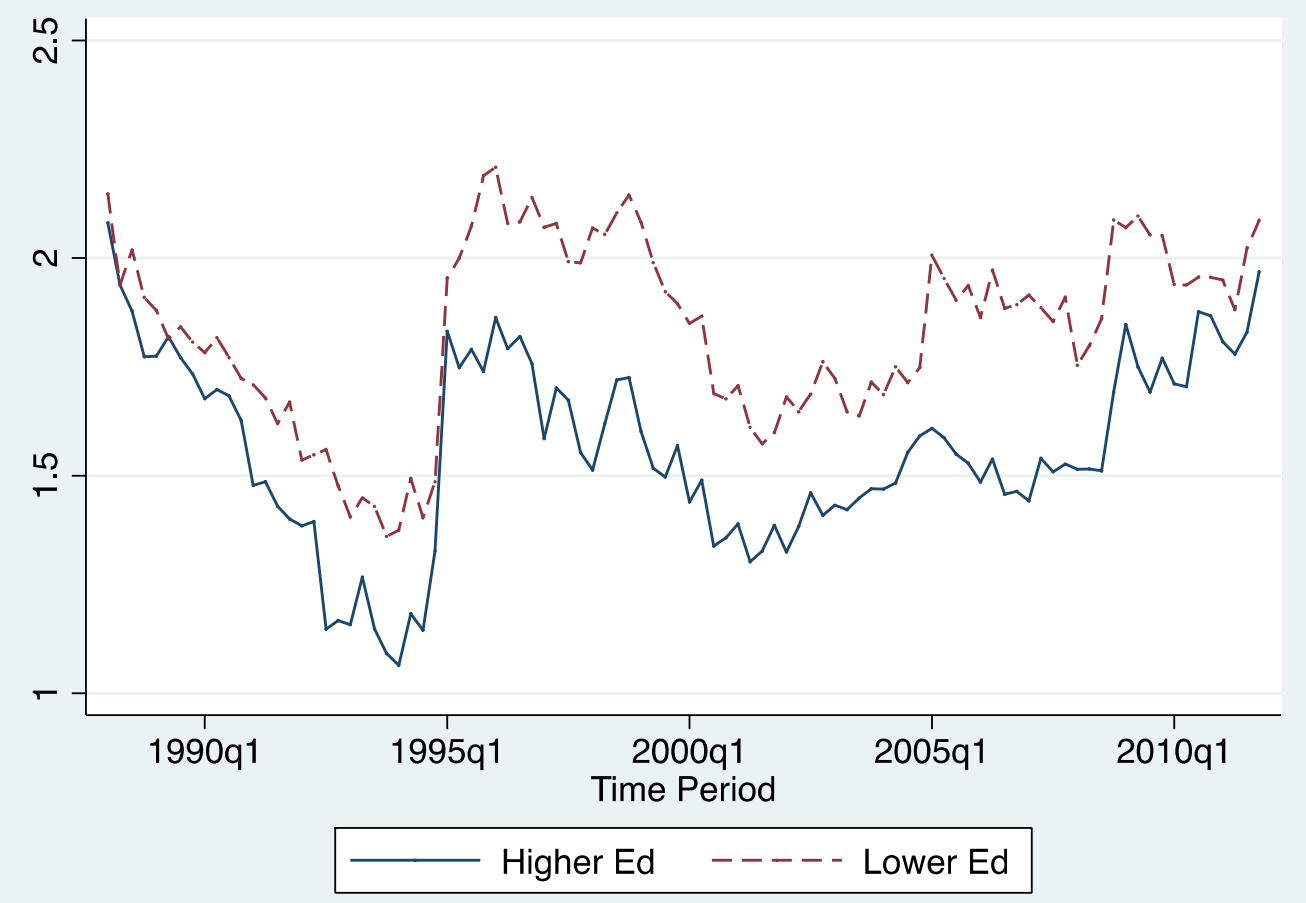

Notes: The higher education group consists of the average of the wage differential across groups 4 and 5 . The lower education group consists of the average of the wage differential across groups 1 and 2. Group three is omitted. 
Figure 7: Changes in Wage Percentiles by Education
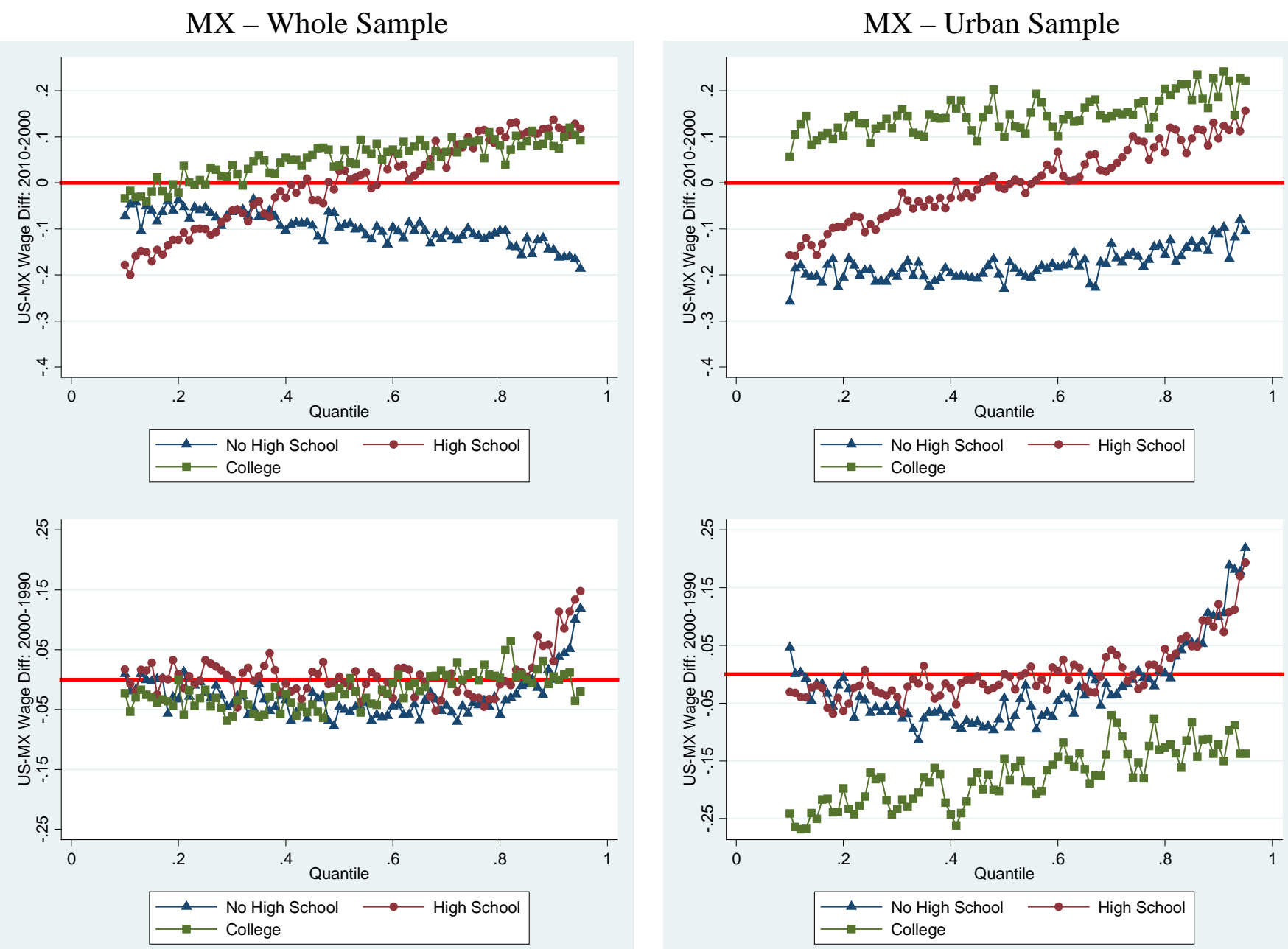

Notes: The solid horizontal line represents zero. The education groups are defined in detail in the text. Data points represent percentiles. 
Figure 8: Decompositions of Wage Distribution Changes by Years
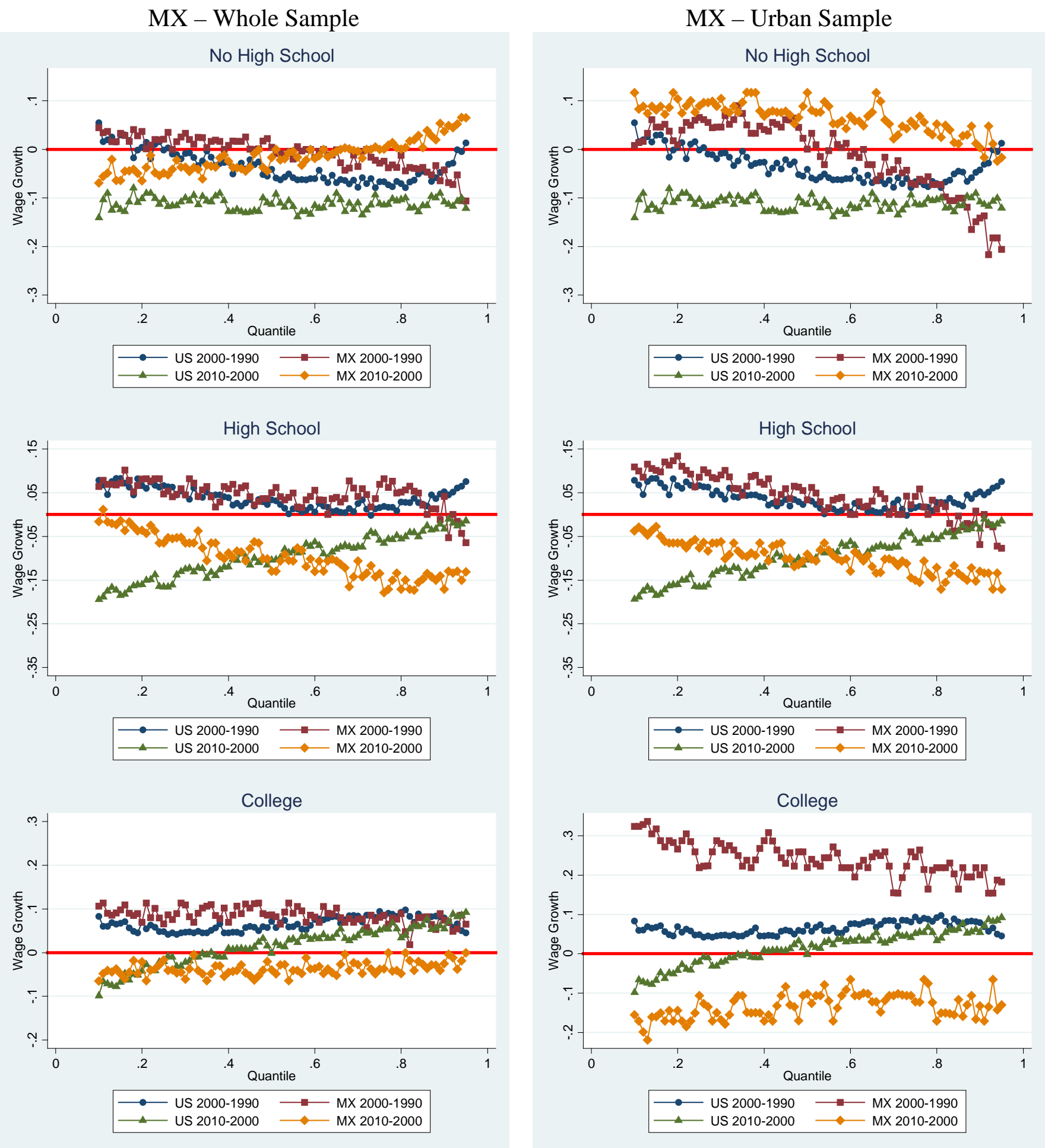
Figure 9: Wage Differentials by Geographic Region

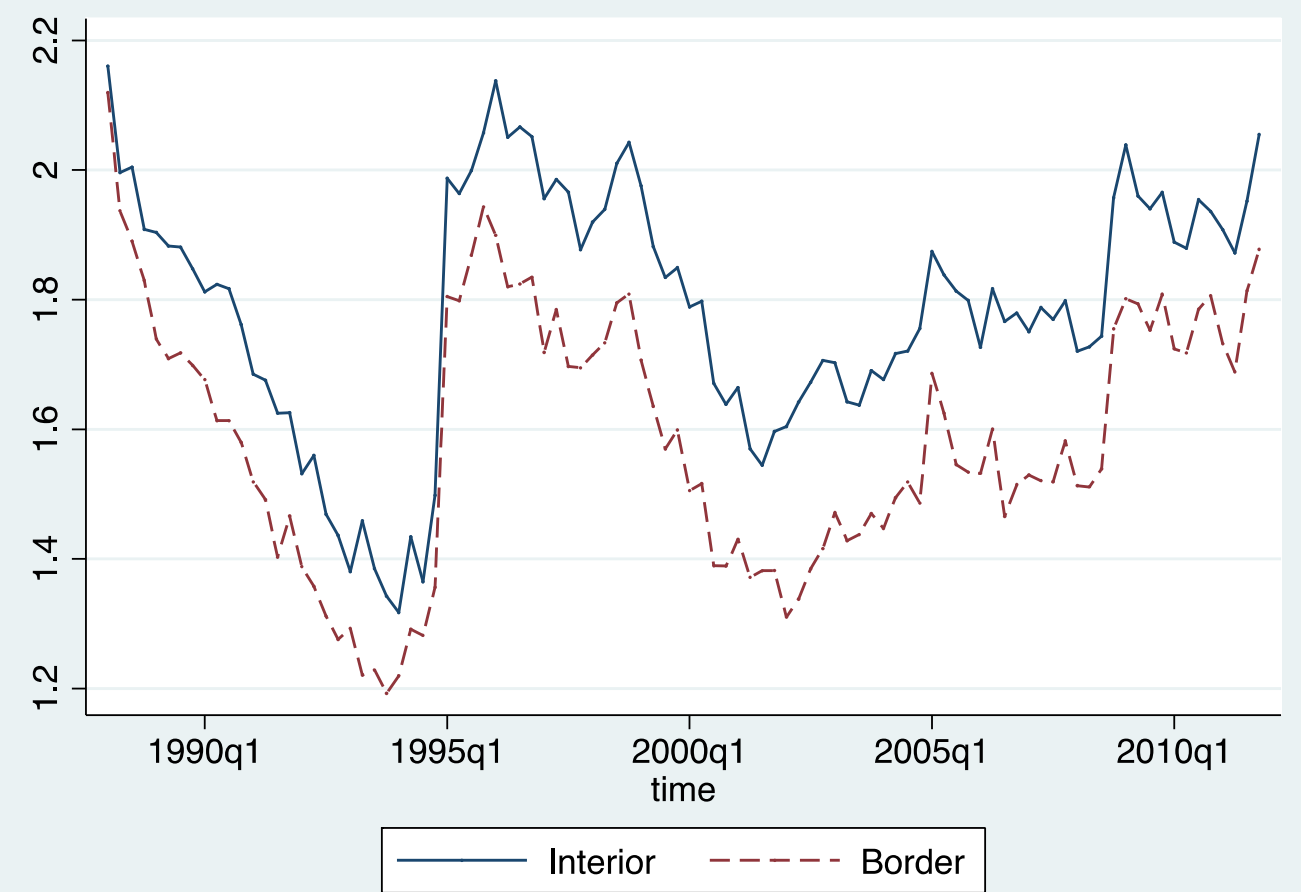

Notes: The border includes Tijuana, Ciudad Juarez, Matamoros, Nuevo Laredo, Chihuahua, Torreon, and Monterrey. The interior includes Mexico City, the State of Mexico, San Luis Potosí, Leon, Guadalajara, Tampico, Durango, Puebla, Tlaxcala, Veracruz, Merida, Orizaba, and Guanajuato. 
Figure 10: DDD Results - Differences in Changes in Wage Percentiles by Education across Mexico's Border and Interior
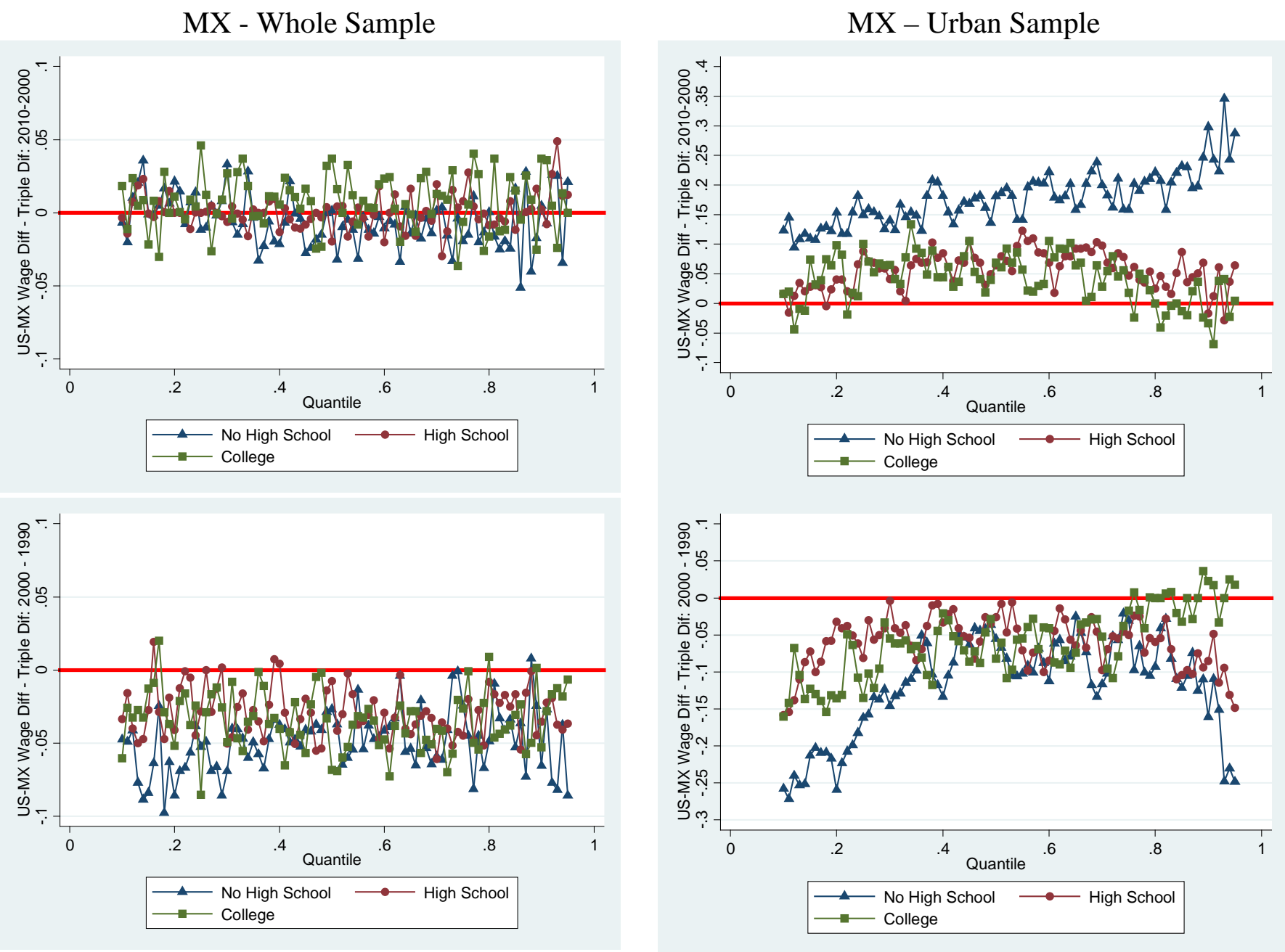